\title{
Multi-gas and multi-source comparisons of six land use emission datasets and AFOLU estimates in the Fifth Assessment Report, for the tropics for 2000-2005
}

\author{
Rosa Maria Roman-Cuesta ${ }^{1,2}$, Martin Herold ${ }^{2}$, Mariana C. Rufino ${ }^{1,3}$, Todd S. Rosenstock ${ }^{4}$, Richard A. Houghton ${ }^{5}$, \\ Simone Rossi ${ }^{6}$, Klaus Butterbach-Bahl ${ }^{7,8}$, Stephen Ogle ${ }^{9}$, Benjamin Poulter ${ }^{10}$, Louis Verchot $^{11,12}$, \\ Christopher Martius ${ }^{2}$, and Sytze de Bruin ${ }^{3}$ \\ ${ }^{1}$ Center for International Forestry Research (CIFOR), P.O. Box 0113 BOCBD, Bogor 16000, Indonesia \\ ${ }^{2}$ Laboratory of Geo-Information Science and Remote Sensing, Wageningen University \& Research, \\ Droevendaalsesteeg 3, 6708PB, Wageningen, the Netherlands \\ ${ }^{3}$ Lancaster Environment Centre, Lancaster University, Lancaster LA14YQ, UK \\ ${ }^{4}$ World Agroforestry Centre (ICRAF), P.O. Box 30677-00100, Nairobi, Kenya \\ ${ }^{5}$ Woods Hole Research Center, 149 Woods Hole Road Falmouth, MA, 02540-1644, USA \\ ${ }^{6}$ Global Environmental Monitoring Unit, Institute for Environment and Sustainability, European Commission, \\ Joint Research Centre, TP, 44021020 Ispra, Varese 21027, Italy \\ ${ }^{7}$ International Livestock Research Institute (ILRI) P.O. Box 30709. Nairobi 00100, Kenya \\ ${ }^{8}$ Karlsruhe Institute of Technology, Institute of Meteorology and Climate Research (IMK-IFU), \\ Garmisch-Partenkirchen, Germany \\ ${ }^{9}$ Natural Resource Ecology Laboratory, Campus Delivery 1499, Colorado State University, Fort Collins, \\ Colorado 80523-1499, USA \\ ${ }^{10}$ Ecosystem Dynamics Laboratory, Montana State University, P.O. Box 172000, Bozeman, MT 59717-2000, USA \\ ${ }^{11}$ International Center for Tropical Agriculture, Km17 Recta Cali-Palmira, Apartado Aéreo 6713, Cali, Colombia \\ ${ }^{12}$ Earth Institute Center for Environmental Sustainability, Columbia University, New York, USA \\ Correspondence to: Rosa Maria Roman-Cuesta (rosa.roman@wur.nl)
}

Received: 4 June 2016 - Published in Biogeosciences Discuss.: 28 June 2016

Revised: 28 September 2016 - Accepted: 3 October 2016 - Published: 24 October 2016

\begin{abstract}
The Agriculture, Forestry and Other Land Use (AFOLU) sector contributes with ca. 20-25\% of global anthropogenic emissions (2010), making it a key component of any climate change mitigation strategy. AFOLU estimates, however, remain highly uncertain, jeopardizing the mitigation effectiveness of this sector. Comparisons of global AFOLU emissions have shown divergences of up to $25 \%$, urging for improved understanding of the reasons behind these differences. Here we compare a variety of AFOLU emission datasets and estimates given in the Fifth Assessment Report for the tropics (2000-2005) to identify plausible explanations for the differences in (i) aggregated gross AFOLU emissions, and (ii) disaggregated emissions by sources and gases $\left(\mathrm{CO}_{2}, \mathrm{CH}_{4}, \mathrm{~N}_{2} \mathrm{O}\right)$.
\end{abstract}

We also aim to (iii) identify countries with low agreement among AFOLU datasets to navigate research efforts. The datasets are FAOSTAT (Food and Agriculture Organization of the United Nations, Statistics Division), EDGAR (Emissions Database for Global Atmospheric Research), the newly developed AFOLU "Hotspots", "Houghton", "Baccini", and EPA (US Environmental Protection Agency) datasets. Aggregated gross emissions were similar for all databases for the AFOLU sector: 8.2 (5.5-12.2), 8.4, and 8.0 $\mathrm{Pg} \mathrm{CO}_{2}$ eq. $\mathrm{yr}^{-1}$ (for Hotspots, FAOSTAT, and EDGAR respectively), forests reached 6.0 (3.8-10), 5.9, 5.9, and $5.4 \mathrm{Pg} \mathrm{CO}_{2}$ eq. $\mathrm{yr}^{-1}$ (Hotspots, FAOSTAT, EDGAR, and Houghton), and agricultural sectors were with 1.9 (1.52.5), 2.5, 2.1, and 2.0 $\mathrm{Pg} \mathrm{CO}_{2}$ eq. $\mathrm{yr}^{-1}$ (Hotspots, FAOSTAT, 
EDGAR, and EPA). However, this agreement was lost when disaggregating the emissions by sources, continents, and gases, particularly for the forest sector, with fire leading the differences. Agricultural emissions were more homogeneous, especially from livestock, while those from croplands were the most diverse. $\mathrm{CO}_{2}$ showed the largest differences among the datasets. Cropland soils and enteric fermentation led to the smaller $\mathrm{N}_{2} \mathrm{O}$ and $\mathrm{CH}_{4}$ differences. Disagreements are explained by differences in conceptual frameworks (carbon-only vs. multi-gas assessments, definitions, land use vs. land cover, etc.), in methods (tiers, scales, compliance with Intergovernmental Panel on Climate Change (IPCC) guidelines, legacies, etc.) and in assumptions (carbon neutrality of certain emissions, instantaneous emissions release, etc.) which call for more complete and transparent documentation for all the available datasets. An enhanced dialogue between the carbon $\left(\mathrm{CO}_{2}\right)$ and the AFOLU (multi-gas) communities is needed to reduce discrepancies of land use estimates.

\section{Introduction}

Modelling studies suggest that, to keep the global mean temperature increase to less than $2{ }^{\circ} \mathrm{C}$ and to remain under $450 \mathrm{ppm}$ of $\mathrm{CO}_{2}$ by $2100, \mathrm{CO}_{2}$ emissions must be cut $41-$ $72 \%$ below 2010 levels by 2050 (IPCC, 2014), and global emissions levels must be reduced to zero (a balance between sources and sinks) before 2070, then to below zero through removal processes (Anderson, 2015; UNEP, 2015). To reach these ambitious goals, tremendously rapid improvements in energy efficiency and nearly a quadrupling of the share of zero and low carbon energy supply, i.e. renewables, nuclear energy, and carbon dioxide capture and storage (CCS), including bioenergy (BECCS), would be needed by 2050 (IPCC, 2014; Friedlingstein et al., 2014; UNEP, 2015). Since there is no scientific evidence on the feasibility of CCS technologies (Anderson, 2015), renewables and the land use sector are among the most plausible options (Canadell and Schulze, 2014). Optimistic estimates suggest that the AFOLU sector (here indistinctively also called land use sector) could contribute from 20 to $60 \%$ of the total cumulative abatement to 2030 including bioenergy (Smith et al., 2014).

The Agriculture, Forestry, and other Land Use (AFOLU) sector roughly contributes a quarter $\left(10-12 \mathrm{Pg} \mathrm{CO}_{2}\right.$ eq. $\left.\mathrm{yr}^{-1}\right)$ of the total anthropogenic greenhouse gas (GHG) emissions (50 $\mathrm{PgCO}_{2}$ eq. $\mathrm{yr}^{-1}$; Smith et al., 2014) through a few human activities: deforestation, forest degradation, and agriculture, including cropland soils, paddy rice, and livestock (Smith et al., 2014). Despite the acknowledged importance of the emissions from the land use sector in global mitigation strategies, assessing GHG emissions and removals from this sector remains technically and conceptually challenging (Abad-
Viñas et al., 2015; Ciais et al., 2014). This challenge relates to an incomplete understanding of the processes that control the emissions from the land use sector (Houghton, 2010; Houghton et al., 2012), especially post-disturbance dynamics (Frank et al., 2015; Poorter et al., 2016), to various sources of error that range from inconsistent definitions, methods, and technical capacities (Romijn et al., 2012, 2015; Abad-Viñas et al., 2015), to special features of the land use sector such as legacy and reversibility/non-permanence effects (Estrada et al., 2014), or to the difficulty of separating anthropogenic and natural emissions (Estrada et al., 2014; Smith et al., 2014). As a result, the AFOLU emissions are the most uncertain of the all the sectors in the global budget, reaching up to $50 \%$ of the emissions mean (Houghton et al., 2012; Smith et al., 2014; Tubiello et al., 2015). This is important since uncertainties jeopardize the effectiveness of the AFOLU sector to contribute to climate change mitigation. Thus, making countries comply with their mitigation targets is likely to be controversial when the uncertainty is equal to or greater than the pledged emission reductions (Grassi et al., 2008; Pelletier et al., 2015).

Currently, data on AFOLU emissions are available through national greenhouse gas inventories, which are submitted to the United Nations Framework Convention on Climate Change (UNFCCC), but these national estimates cannot be objectively compared due to differences in definitions, methods, and data completeness (Houghton et al., 2012; Abad-Viñas et al., 2015). More comparable AFOLU data are offered in global emission databases such as EDGAR (Emissions Database for Global Atmospheric Research) or FAOSTAT (Food and Agriculture Organization Corporate Statistical Database)(Smith et al., 2014; Tubiello et al., 2015), or more sectorial datasets such as the Houghton Forestry and other Land Use (FOLU) data (Houghton et al., 2012), and the US Environmental Protection Agency non- $\mathrm{CO}_{2}$ emissions for agriculture, including livestock (USEPA, 2013). While national inventories and global databases are currently the best bottom-up emissions data we count on, their ability to inform us on what the atmosphere receives has been contested. Recent research shows disagreements between the trends of reported emissions and atmospheric growth since 1990 for $\mathrm{CO}_{2}$ (Francey et al., 2010, 2013a, b), for $\mathrm{CH}_{4}$ (Montzka et al., 2011), and for $\mathrm{N}_{2} \mathrm{O}$ (Francey et al., 2013b). In the case of $\mathrm{CO}_{2}$, Francey et al. conclude that the differences between atmospheric and emission trends for $\mathrm{CO}_{2}$ might be more related to under-reported emissions ( $\sim 9 \mathrm{PgC}=33 \mathrm{PgCO}_{2}$ for the period 1994-2005) than to adjustments in the terrestrial sinks (i.e. increased $\mathrm{CO}_{2}$ removals in oceans and forests). On the other hand, global AFOLU databases suffer from inconsistencies that lead to global $\mathrm{CO}_{2}$ eq. emissions differences of up to $25 \%$ (2000-2009; Tubiello et al., 2015), which are 12.7 and $9.9 \mathrm{Pg} \mathrm{CO}_{2}$ eq. $\mathrm{yr}^{-1}$ for EDGAR and FAOSTAT respectively. These datasets also disagreed in the contribution of the AFOLU sector to the total anthropogenic budget in 2010 (i.e. 21 and $24 \%$ for FAO- 
STAT vs. EDGAR; Tubiello et al., 2015) and on the relative share of the emissions from agriculture compared to FOLU since 2010 Tubiello et al., 2015). Thus, while EDGAR implies a relatively equal contribution (IPCC, 2014), FAOSTAT reports agricultural emissions as being larger contributors to the total anthropogenic budget $(11.2 \pm 0.4 \%)$ than forestry and other land uses (10 $\pm 1.2 \%$; Tubiello et al., 2015), with a steady growth trend of $1 \%$ since 2010 .

Understanding the inconsistencies among AFOLU datasets is an urgent task since they preclude our accurate understanding of land-atmosphere interactions, GHG effects on climate forcing and, consequently, the utility of modelling exercises and policies to mitigate climate change (Houghton et al., 2012; Grace et al., 2014; Smith et al., 2014; Sitch et al., 2015; Tian et al., 2016). The land use sector plays a prominent role in the Paris Agreement (Article 5), with many countries including it in their mitigation targets for their Nationally Determined Contributions (NDCs; Grassi and Dentener, 2015; Richards et al., 2015; Streck, 2015). It is then urgent to understand how much and why different AFOLU datasets differ in their emission estimates, so that we can better navigate countries' land-based mitigation efforts, and help to validate their proposed claims under the UNFCCC.

Here we compare gross AFOLU emissions estimates for the tropics, for 2000-2005, from six datasets: FAOSTAT, EDGAR, Houghton, Baccini, the US Environmental Protection Agency data (EPA), and a recently produced, spatially explicit AFOLU dataset, that we will hereafter call Hotspots (Roman-Cuesta et al,. 2016). We aim to identify differences and plausible explanations behind (i) aggregated AFOLU, FOLU, and agricultural gross emissions, (ii) disaggregated contributions of the emission sources for the different datasets, (iii) disaggregated contribution of the different gases $\left(\mathrm{CO}_{2}, \mathrm{CH}_{4}, \mathrm{~N}_{2} \mathrm{O}\right)$, and (iv) national-scale disagreements between datasets.

\section{Methods}

\subsection{Study area}

Our study area covers the tropics and the subtropics, including the more temperate regions of South America $\left(33^{\circ} \mathrm{N}\right.$ to $54^{\circ} \mathrm{S}, 161^{\circ} \mathrm{E}$ to $\left.117^{\circ} \mathrm{W}\right)$. Land use change occurs nowhere more rapidly than in the tropics (Poorter et al., 2016) so its study has global importance. Moreover, the tropics suffer from the largest data and capacity gaps (Romijn et al., 2012, 2015), and their need to access AFOLU data and understand their differences is more crucial. We selected the period 2000-2005 for being the common temporal range for all the datasets. This period is not for the recent past but that does not affect the comparative nature of this research. Our study area focuses at the country level and includes 80 countries, following Harris et al. (2012). We ran the compar- isons on gross emissions. While gross and net emissions are equally important, they offer different information (Richter and Houghton, 2011; Houghton et al., 2012). Net land use emissions consider the emissions by the sources and the removals by the sinks (i.e. forest growth, forest regrowth after disturbances, organic matter stored in soils) in a final emission balance where the removals are discounted from the emissions. Gross assessments can consider both the emissions produced by the sources (gross emissions) and the removals absorbed by the sinks (gross removals), but they are not balanced out. Gross emissions are useful to navigate mitigation implementation since they offer direct information on the sources and sinks that need to be acted upon through policies and measures to enhance and promote mitigation (see further information on net and gross alternatives in RomanCuesta et al., 2016).

\subsection{AFOLU datasets}

\subsubsection{Hotspots}

This is a multi-gas $\left(\mathrm{CO}_{2}, \mathrm{CH}_{4}, \mathrm{~N}_{2} \mathrm{O}\right)$ spatially explicit $\left(0.5^{\circ}\right)$ database on gross AFOLU emissions and associated uncertainties for the tropics and subtropics for the period 2000 2005, at Tier 2 and Tier 3 levels (see Supplement for the definition of tiers). This database locates the hotspots of tropical AFOLU emissions, which should help to estimate mitigation potentials, and prioritize the areas and the land activities that require most urgent mitigation action. It combines available published GHG datasets for the key sources of emissions in the AFOLU sector as identified by the Fifth Assessment Report of the Intergovernmental Panel on Climate Change (AR5, Smith et al., 2014): deforestation, forest degradation (fire, wood harvesting), crop soils, paddy rice, and livestock (enteric fermentation and manure management). It also includes agricultural peatland decomposition using Tier 1 emission factors (see details in Roman-Cuesta et al., 2016). Forest emissions focus on aboveground biomass, with the exception of peat fires. More detailed methodological information is available in Roman-Cuesta et al. (2016).

\subsubsection{FAOSTAT}

FAOSTAT covers agriculture, forestry, and other land uses and their associated emissions of $\mathrm{CO}_{2}, \mathrm{CH}_{4}$ and $\mathrm{N}_{2} \mathrm{O}$, following IPCC, 2006 guidelines at Tier 1 (Tubiello et al., 2013, 2014). Emissions are estimated for nearly 200 countries annually, for the reference period of 1961-2012 (agriculture) and 1990-2012 (FOLU), based on national activity data submitted by countries and further collated by FAO (Food and Agriculture Organization of the United Nations). Projected emission data are available for 2030 and 2050. FAOSTAT includes estimates of emissions from biomass fires, peatland drainage, and fires, based on geospatial information, as well as on forest carbon stock changes (both emissions and re- 
movals) based on national-level FAO Forest Resources Assessment data (FRA, 2010).

\subsubsection{EDGAR}

The Emissions Database for Global Atmospheric Research (EDGAR) provides global GHG emissions from multiple gases $\left(\mathrm{CO}_{2}, \mathrm{CH}_{4}, \mathrm{~N}_{2} \mathrm{O}\right.$, HFCs, PFCs, and SF6) at $0.1^{\circ}$ and country levels. The EDGAR database covers all IPCC sectors (energy, industry, waste management, and AFOLU), mostly applying IPCC 2006 guidelines for emission estimations (EDGAR, 2012). We downloaded the EDGAR 4.2 Fast Track 2010 (FT 2010). FT 2010 emissions cover the period 2000-2010 on an annual basis, at the country level.

\subsubsection{Houghton}

Houghton's bookkeeping model calculates the net and gross fluxes of carbon $\left(\mathrm{CO}_{2}\right.$ only) between land and atmosphere that result from land management (Houghton, 1999, 2012; Houghton and Hackler, 2001; Houghton et al., 2012). The net estimate includes emissions of $\mathrm{CO}_{2}$ from deforestation, shifting cultivation, wood harvesting, wood debris decay, biomass burning (for deforestation fires only, peatland fires were not included in our version of their data), and soil organic matter from cultivated soils. It also includes sinks of carbon in forests recovering from harvest and agricultural abandonment under shifting cultivation. The model, however, does not include forests that are not logged, cleared, or cultivated. Rates of growth and decomposition are ecosystem specific and do not vary in response to changes in climate, $\mathrm{CO}_{2}$ concentrations, or other elements of environmental change. Therefore, forests grow (and wood decays) at the same rates in 1850 and 2015. Unlike other databases, all carbon in a considered ecosystem is accounted for in live vegetation, soil, slash (woody debris produced during disturbance), and wood products. We downloaded regional annual emissions from the TRENDS (1850-2005) dataset for the tropics: Central and South (CS) America, tropical Africa, and South and South East Asia. Only net emissions were available. No spatially disaggregated data were offered (i.e. countries). Houghton data are, unlike all the other datasets, net aggregated FOLU estimates for $\mathrm{CO}_{2}$ only.

\subsubsection{Baccini}

These are gross FOLU tropical emissions published by Baccini et al. (2012). Data are gross emissions for the period 2000-2010 disaggregated into deforestation (4.18 $\left.\mathrm{PgCO}_{2} \mathrm{yr}^{-1}\right)$, wood harvesting $\left(1.69 \mathrm{PgCO}_{2} \mathrm{yr}^{-1}\right)$, biomass burning $\left(2.86 \mathrm{PgCO}_{2} \mathrm{yr}^{-1}\right)$, and wood debris decay (3.04 $\mathrm{PgCO}_{2} \mathrm{yr}^{-1}$ ). We excluded this last variable to make it more comparable to the other datasets, where CWD is frequently excluded (Table 1). Baccini estimates refer to a tropical area slightly smaller than our study region and they are of- fered as an aggregated value (no continental or country data are available).

\subsubsection{The US Environmental Protection Agency (EPA)}

The EPA dataset contains global non- $\mathrm{CO}_{2}$ projected emissions for the period 1990-2030 for the agriculture, energy, industrial processes, and waste sectors, for more than twenty gases. EPA uses future net emissions projections of non$\mathrm{CO}_{2}$ GHGs as a basis for understanding how future policy and short-term, cost-effective mitigation options can affect these emissions. EPA follows the Global Emissions Report, which uses a combination of country-prepared, publicly available reports consistent with IPCC guidelines and guidance (USEPA, 2013). When national emissions estimates were unavailable, EPA produced its own non- $\mathrm{CO}_{2}$ emissions using IPCC methodologies (i.e. international statistics for activity data, and the default IPCC Tier 1 emission factors). Deviations to this methodology are discussed in each of the source-specific methodology sections of USEPA (2012). No FOLU estimates are included in this dataset. We downloaded agricultural emissions offered at 5-year intervals at country level, disaggregated by gas $\left(\mathrm{N}_{2} \mathrm{O}\right.$ and $\left.\mathrm{CH}_{4}\right)$ and by emission sources.

\subsubsection{IPCC AR5}

The AR5 is a synthesis report, not a repository of global data. However, new AFOLU data are produced by merging peer-reviewed data such as Figs. 11.2, 11.4, 11.5, and 11.8 in chapter 11 of the AR5 (Smith et al., 2014). We will compare our six datasets with the data from these newly produced figures.

Table 1 shows a summary of key similarities and differences of the assessed AFOLU datasets and the data from the AR5. The exact variables used for each database are described in Table S1 in the Supplement.

\subsection{Estimating comparable gross AFOLU emissions for all datasets}

We focus on human-induced gross emissions only, excluding fluxes from unmanaged land (i.e. natural wetlands). We focus on direct emissions excluding indirect emissions whenever possible (i.e. nitrate leaching and surface run-off from croplands). Delayed fluxes (legacies) are important (i.e. underestimations of up to $62 \%$ of the total emissions when recent legacy fluxes are excluded; Houghton et al., 2012) but are frequently omitted in GHG assessments that are derived from remote sensing, such as the deforestation emissions used in the Hotspots database, which relies on Harris et al., 2012). Wood-harvesting emissions also excluded legacy fluxes. We assumed instantaneous emissions of all carbon that is lost from the land after human action (Tier 1, IPCC, 2006; i.e. deforested and harvested wood), with no transboundary considerations (i.e. the emissions are assigned wherever the distur- 
Table 1. Differences and similarities of the assessed AFOLU datasets.

\begin{tabular}{|c|c|c|c|c|c|c|c|}
\hline & Hotspots & FAOSTAT & EDGAR & Houghton & Baccini & EPA & AR5 \\
\hline Gross/net emissions & Gross & Gross & Gross & Net & Gross & Gross & Net \\
\hline Uncertainty $^{\mathrm{a}}$ & $\sqrt{ }$ & No & No & No & No & No & $\sqrt{ }$ \\
\hline Transparency & High & High & Low $^{b}$ & Low & Low & Intermediate & Low \\
\hline IPCC compliant & $\sqrt{ }$ & & $\sqrt{ }$ & Not fully ${ }^{\mathrm{c}}$ & Not fully ${ }^{\mathrm{d}}$ & $\sqrt{ }$ & Not fully \\
\hline Forest carbon pools & AGB and BGB & AGB and BGB & AGB & $\begin{array}{l}\text { AGB and BGB and Soil } \\
+ \text { CWD and Litter }\end{array}$ & $\begin{array}{r}\text { AGB and BGB and } \\
\text { Soil and CWDvLitter }\end{array}$ & Soil & $\begin{array}{l}\text { AGB and BGB and Soil } \\
+ \text { CWD and Litter }\end{array}$ \\
\hline Gases & $\begin{array}{r}\mathrm{CO}_{2}, \mathrm{CH}_{4}, \\
\mathrm{~N}_{2} \mathrm{O}\end{array}$ & $\begin{array}{r}\mathrm{CO}_{2}, \mathrm{CH}_{4}, \\
\mathrm{~N}_{2} \mathrm{O}\end{array}$ & $\begin{array}{r}\mathrm{CO}_{2}, \mathrm{CH}_{4}, \\
\mathrm{~N}_{2} \mathrm{O}\end{array}$ & $\mathrm{CO}_{2}$ & $\mathrm{CO}_{2}$ & $\begin{array}{r}\mathrm{CO}_{2}, \mathrm{CH}_{4}, \\
\mathrm{~N}_{2} \mathrm{O}\end{array}$ & $\begin{array}{r}\mathrm{CO}_{2} \text { for forests. } \\
\mathrm{CO}_{2}, \mathrm{CH}_{4} \\
\mathrm{~N}_{2} \mathrm{O} \text { for agriculture } \\
\text { and peatlands. }\end{array}$ \\
\hline Tier 1 & $\sqrt{ }$ & $\sqrt{ }$ & $\sqrt{ }$ & & & $\sqrt{ }$ & - \\
\hline Tier 2,3 & $\sqrt{ }$ & & & $\sqrt{ }$ & $\sqrt{ }$ & $\sqrt{ }$ & - \\
\hline Spatial disaggregation ${ }^{\mathrm{f}}$ & Pixel $\left(0.5^{\circ}\right)$ & Country & Country ${ }^{\mathrm{g}}$ & Region & Region & Country & Region \\
\hline Peatlands & $\sqrt{ }$ & $\sqrt{ }$ & $\sqrt{ }$ & No & No & No & $\sqrt{ }$ \\
\hline
\end{tabular}

bance takes place, particularly important for Harvested Wood Products). Life cycle substitution effects were neither considered for harvested wood (Peters et al., 2012). Some exceptions were allowed when data were already aggregated (i.e. for the Houghton and EPA datasets we could not exclude indirect emissions linked to forest decay and agriculture respectively), or because their legacy (past decay) estimates corresponded to an important source (i.e. EDGAR post-burned decay and decomposition emissions represent deforestation; Tubiello et al., 2015). Databases include a diversity of emission sources and gases under AFOLU, not always following IPCC requirements (some exclude peatland emissions, some include energy into the AFOLU emissions, some exclude non-CO2 emissions, etc.). However, to compare the AFOLU emission estimates between databases, we choose exactly the same sources: deforestation, wood harvesting, fire, livestock (enteric fermentation and manure management), cropland soil emissions, rice emissions, emissions from drained histosols, and the same gases $\mathrm{CO}_{2}, \mathrm{CH}_{4}$, and $\mathrm{N}_{2} \mathrm{O}$, and documented what was included in each case (See Table S1). For the case of fire, for all the databases, we excluded $\mathrm{CO}_{2}$ emissions that came from biomass burning in non-woody vegetation such as savannas and agriculture, since they are assumed to be in equilibrium with annual regrowth processes (for $\mathrm{CO}_{2}$ gases only; IPCC 2003, 2006).

\subsection{Correcting known differences among dataset estimates}

Tubiello et al. (2015) identified four main differences that resulted in larger estimates for the EDGAR data than for FAOSTAT, under the AFOLU estimates of the AR5 (Smith et al., 2014): (1) the inclusion of energy emissions under the agriculture budget, (2) the inclusion of savanna burning, (3) higher rice emissions due to the use of the IPCC 1996 guidelines instead of the IPCC 2006 guidance, and (4) FOLU's unresolved differences due to unclear metadata on EDGAR's proxy for deforestation (post-burned decay and decomposition). We have corrected for the first two in our data comparison. No energy or $\mathrm{CO}_{2}$ for savanna burning have been included in the AFOLU estimates in any of our analyses.

\subsection{Country emissions}

To characterize the emission variability between countries we estimated the standard deviations for the different emission sectors: (i) forest (deforestation, fire, and wood harvesting), (ii) agriculture (cropland soils and paddy rice), (iii) livestock, and the aggregated AFOLU emissions, for the three most complete datasets (Hotspots, FAOSTAT, EDGAR), per country. We grouped the standard deviations into four percentiles to aggregate countries into levels of emission variability: high agreement (corresponds to low variability, low standard deviations, $<25$ th percentile), moderate agreement (25th-50th percentiles), low agreement (25th-50th percentiles), and very low agreement (equals very high variability, very high standard deviations, $>75$ th percentile) See Supplement for a further discussion on issues regarding emission variability.

\section{Results and discussion}

\subsection{Aggregated AFOLU, FOLU, and agricultural emissions}

We found good agreement among datasets for the aggregated tropical scales with AFOLU values of 8.0 (5.5-12.2; 5th-95th percentiles), 8.4 and $8.0 \mathrm{Pg} \mathrm{CO}_{2}$ eq. $\mathrm{yr}^{-1}$ (for the Hotspots, FAOSTAT, and EDGAR respectively). FOLU (deforestation and forest degradation) contributed with 6.0 (3.810), 5.9, 5.9, and 5.4 $\mathrm{PgCO}_{2}$ eq. $\mathrm{yr}^{-1}$ for the Hotspots, FAOSTAT, EDGAR, and Houghton datasets respectively. Agriculture (livestock, cropland soils, and rice emissions) 
Table 2. Summary of (a) tropical gross emissions estimates for agriculture, FOLU (Forestry and Other Land Use), and AFOLU (Agriculture, Forestry, and Other Land Use) for all the datasets (Hotspots, FAOSTAT, EDGAR, EPA, Houghton; 2000-2005) and published data (Baccini et al., 2012; AR5 Smith et al., 2014; 2000-2007), and of (b) net global estimates as reported by Tubiello et al. (2015). Houghton and EPA respectively offer FOLU and agricultural data only; therefore estimates for AFOLU are not complete.

\begin{tabular}{|c|c|c|c|c|c|c|c|}
\hline \multicolumn{8}{|c|}{ Gross tropical $\left(\mathrm{PgCO}_{2}\right.$ eq. $\left.\mathrm{yr}^{-1}\right)$} \\
\hline \multirow[t]{2}{*}{ (a) } & \multicolumn{5}{|c|}{ 2000-2005 } & \multicolumn{2}{|c|}{ 2000-2007 } \\
\hline & Hotspots & FAOSTAT & EDGAR-JRC & Houghton & EPA & Baccini & AR5 \\
\hline Agriculture & $1.9(1.5-2.5)$ & 2.5 & 2.1 & - & 2.0 & - & \\
\hline FOLU & $6(3.8-10)$ & 5.9 & 5.9 & $5.4^{\mathrm{a}}$ & - & $12.3^{\mathrm{b}}$ & $8.2^{\mathrm{c}}$ \\
\hline AFOLU & $8(5.5-12.2)$ & 8.4 & 8 & - & - & - & \\
\hline \multicolumn{8}{|c|}{ Net global $\mathrm{Pg} \mathrm{CO}_{2}$ eq. $\mathrm{yr}^{-1}$} \\
\hline \multirow[t]{2}{*}{ (b) } & & 2000 & & & 2010 & & $2000 / 09$ \\
\hline & FAOSTAT & EDGAR-JRC & Houghton & FAOSTAT & EDGAR-JRC & Houghton & AR5 \\
\hline Agriculture & 5 & 5.5 & - & 5.2 & 5.8 & - & 5 \\
\hline FOLU & 4.9 & 6.5 & 4.9 & 4.9 & 5.5 & 4.2 & 5 \\
\hline AFOLU & 9.9 & 12 & - & 10.1 & 11.3 & - & 10 \\
\hline
\end{tabular}

a Data exposed in Figure 11.2 in chapter 11, Smith et al. (2014). They correspond to a net FOLU estimate without agriculture. ${ }^{\mathrm{b}}$ Baccini et al. (2012) reported gross estimates for the FOLU components. ${ }^{\mathrm{c}}$ Baccini et al. (2012) estimates selected for the AR5 FOLU values in Figure 11.8, Chapter 11, WG-III.

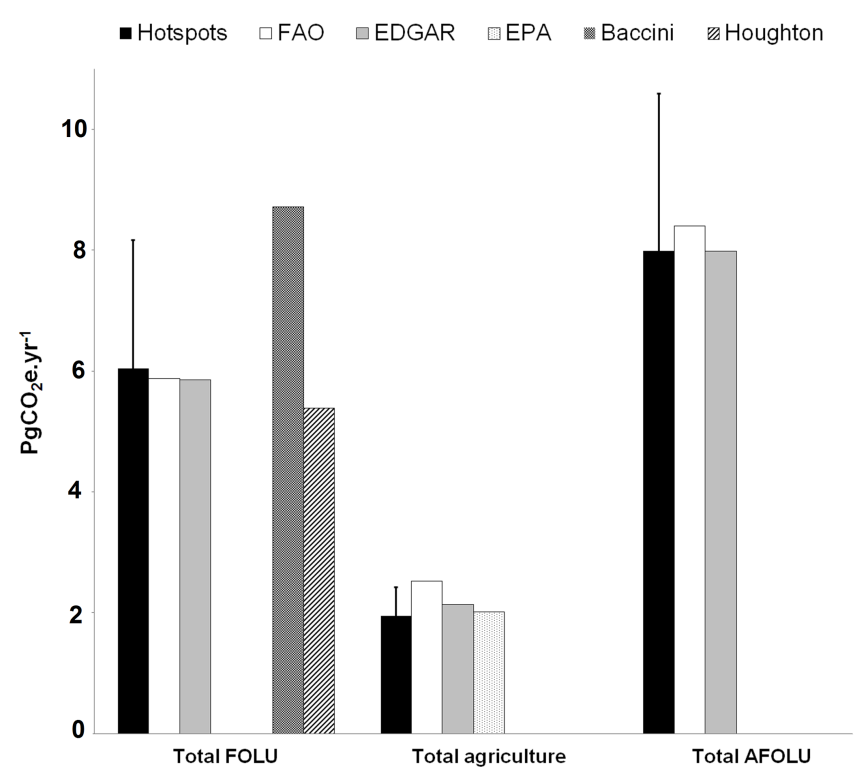

Figure 1. AFOLU (Agriculture, Forestry, and Other Land Use) emissions estimates $\left(\mathrm{PgCO}_{2}\right.$ eq. $\mathrm{yr}^{1}{ }^{1}$ ) for the period $2000-2005$ for the tropics, for six datasets (Hotspots, FAO (FAOSTAT), EDGAR, EPA, Baccini and Houghton), disaggregated into FOLU (Forestry and Other Land Use) and Agricultural emissions. Uncertainties are only provided in the Hotspots dataset ( $1 \sigma$ from the mean). EPA data do not include a FOLU sector. Houghton and Baccini are FOLU, $\mathrm{CO}_{2}$ only, datasets and do not include agricultural emissions. Houghton offers net emissions while Baccini data are gross emissions for deforestation, fire and wood harvesting (Baccini et al., 2012). reached 1.9 (1.5-2.5), 2.5, 2.1, and 2.0 $\mathrm{Pg} \mathrm{CO}_{2}$ eq. $\mathrm{yr}^{-1}$ for the Hotspots, FAOSTAT, EDGAR, and EPA datasets respectively (Fig. 1, Table 2). Forest emissions represented $\geq 70 \%$ of the tropical AFOLU gross mean annual budget for 2000-2005 (the Hotspots database and Houghton showing the highest and lowest estimates), and agriculture represented the remaining 25-30\% AFOLU emissions (FAOSTAT and Hotspots showing the highest and the lowest values). Houghton's FOLU value $\left(5.4 \mathrm{PgCO}_{2} \mathrm{yr}^{-1}\right)$ is a net estimate that includes carbon dynamics associated to forest land use changes, and forest removals from areas under logging and shifting cultivation and it is, as expected, lower than the forest gross emissions. Its value for the tropics, however, was higher than the net FOLU value used in the IPCC AR5 (4.03 $\mathrm{Pg} \mathrm{CO}_{2}$ eq. $\mathrm{yr}^{-1}$ for 2000-2009; Houghton et al., 2012). Since boreal and temperate forest sinks are reported to be quasi-neutral (Houghton et al., 2012), these differences are unclear. There is a variety of Houghton net FOLU estimates in the current bibliography, i.e. $4.03 \mathrm{Pg} \mathrm{CO}_{2}$ eq. $\mathrm{yr}^{-1}$ for 2000-2009 in Smith et al. (2012), 4.9 for 2000, and 4.2 for 2010 (Tubiello et al., 2015), which likely correspond to different updates of the same dataset, but create confusion and would call for verified official values that could be consistently used.

The IPCC AR5 offers a FOLU gross value for the tropics of ca. 8.4 $\mathrm{PgCO}_{2} \cdot \mathrm{yr}^{-1}$ (2000-2007; Fig. 11.8 in AR5, Smith et al., 2014; Fig. S1, Supplement) which corresponds to Baccini estimates using Houghton's bookkeeping model. This value is in the upper range of the Hotspots gross FOLU emissions: 6 (3.8-10) $\mathrm{Pg} \mathrm{CO}_{2}$ eq. $\mathrm{yr}^{-1}$ (2000-2005), and higher than the mean gross FOLU emissions from all the other 


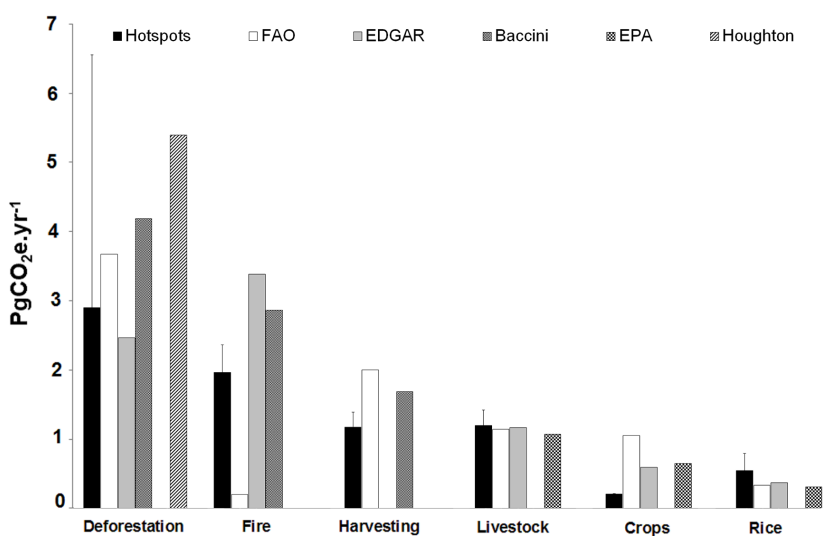

Figure 2. Tropical gross annual emissions (2000-2005) comparisons for the leading emission sources in the AFOLU sector, for the Hotspots, FAOSTAT, EDGAR, Baccini, EPA, and Houghton datasets. Bars indicate uncertainty estimates ( $\sigma \sigma$ from mean). No uncertainty estimates are available for the other datasets. Houghton data are net land use emissions (Forestry and Other Land Use) rather than deforestation and are offered for visual comparisons with the Baccini gross deforestation estimate which includes gross deforestation, fire and wood harvesting. No uncertainty estimates are available for the other datasets. EPA data do not cover forest emissions. Forest degradation is the sum of fire and wood-harvesting emissions.

datasets (approx. $6 \mathrm{PgCO}_{2}$ eq. $\mathrm{yr}^{-1}$; Table 2). The time periods are not identical and we do not compare the same gases (i.e. the bookkeeping model focuses on $\mathrm{CO}_{2}$ only, while we run a multi-gas assessment). However, the differences mainly relate to unreported choices behind the inclusion/exclusion of emission sources and the description of their methods in the AR5. Thus, the $8.4 \mathrm{PgCO}_{2} \mathrm{yr}^{-1}$ gross estimate does not include fire, and has larger contributions from shifting cultivation $\left(2.35 \mathrm{PgCO}_{2} \mathrm{yr}^{-1}\right)$ and wood harvesting $\left(2.49 \mathrm{PgCO}_{2} \mathrm{yr}^{-1}\right)$ than the deforestation and wood-harvesting emissions in the Hotspots-selected datasets (Fig. 2). Numbers used in Fig. 11.8 also exclude other gross emissions offered in Baccini et al. (2012), which is the citation used in Fig. 11.8. Explicit, complete, and transparent documentation is encouraged for the next AFOLU figures in the IPCC Assessment Reports. Another consideration of AFOLU estimates in the Assessment Reports relates to the use of the bookkeeping model to estimate land use, land use change, and forest (LULUCF) emissions. As useful as this model is, its framework does not follow the IPCC AFOLU guidelines (IPCC, 2006), particularly regarding the concept of managed land. Thus, forests that are on managed land but are not suffering from direct human activities are considered carbon neutral (R. Houghton personal communication, 2016). Partly because of that, the net emission estimates of LULUCF from Houghton et al. (2012) used in the AR5 (4.03 $\mathrm{PgCO}_{2} \mathrm{yr}^{-1} 2000-2009$ ) differ from LULUCF country reports for the same period, which are close to zero (Grassi and Dentener, 2015; Federici et al., 2016). The use of IPCC compliant models for the IPCC Assessment Reports, or/and some documentation that warned about these inconsistencies would be useful in future assessments.

Emissions in the agricultural sector are mostly net, since sink effects in the soils are small and frequently temporal (USEPA, 2013; Smith et al., 2014). Comparisons with global agricultural emissions show that for the year 2000, global estimates more than doubled the Hotspots values (i.e. 5 and 5.5 $\mathrm{Pg} \mathrm{CO}_{2}$ eq. $\mathrm{yr}^{-1}$ vs. ca. $2 \mathrm{Pg} \mathrm{CO}_{2}$ eq. $\mathrm{yr}^{-1}$ in all datasets; Tubiello et al., 2015; Table 2), suggesting larger contributions of agricultural emissions from non-tropical countries. Unexplained methodological differences, such as the inclusion or not of indirect emissions and the lack of an exhaustive list of the variables included in the agricultural emissions, result in difficult further comparisons.

\subsection{Disaggregated gross emissions: contributions of the emission sources}

While the gross aggregated estimates suggested a good level of agreement among datasets (Fig. 1), differences occur when comparing the emissions sources leading to the AFOLU budgets (Fig. 2). The FOLU sector showed the largest differences, mainly due to the estimates of forest degradation, and particularly fire (FAOSTAT and EDGAR showed the lowest and highest values). The forest sector is the most uncertain term in the AFOLU emissions due to both uncertainties in areas affected by land use changes and other disturbances, and by uncertain forest carbon densities (Houghton et al., 2012; Grace et al., 2014; Smith et al., 2014). Agricultural sources were more homogeneous (ca. $2 \mathrm{Pg} \mathrm{CO}_{2}$ eq. $\mathrm{yr}^{-1}$ for all datasets; Fig. 1), with livestock and cropland soil emissions as the most and least similar (Fig. 2). The homogeneity in livestock emissions was expected since most datasets use common statistics (FAO) to derive herd numbers per country.

\subsubsection{Deforestation}

Deforestation emissions were 2.9 (1.0-10.1), 3.7, 2.5, and 4.2 $\mathrm{PgCO}_{2} \mathrm{yr}^{-1}$ (for Hotspots, FAOSTAT, EDGAR, and Baccini respectively), with Baccini and EDGAR showing the highest and the lowest values. However, their values represent very different scenarios: gross deforestation for the Hotspots and Baccini datasets (forest losses only), net deforestation for FAOSTAT (forest losses minus forest gains), and forest fire and post-burn decay for EDGAR (Table 3). The Hotspots dataset (Harris et al., 2012 and Baccini et al., 2012) offers gross deforestation estimates that rely on Hansen et al. (2010)'s forest cover loss areas. However, they report different tropical emissions ( 0.81 and $\left.1.14 \mathrm{PgC}_{\mathrm{yr}}{ }^{-1}\right)$ because they use different carbon density maps: Harris et al. (2012) rely on Saatchi et al. (2011) and Baccini rely on Baccini et al. (2010). EDGAR does not provide a category for de- 
Table 3. Characteristics of the emission sources used in this comparative assessment disaggregated by greenhouse gases for the period 20002005, for the Hotspots, FAOSTAT, EDGAR, EPA, Houghton, and Baccini datasets (based on gross emissions from Baccini et al., 2012). Superindices specify differences between datasets and/or indicate the exact data included in our database comparisons. EPA offers only non$\mathrm{CO}_{2}$ emissions for agriculture. Houghton offers only $\mathrm{CO}_{2} \mathrm{FOLU}$ emissions. Baccini gross emissions include deforestation, fire, and wood harvesting only. dSOC refers to changes in soil organic carbon. Wood harvesting and fire are considered as forest degradation.

\begin{tabular}{|c|c|c|c|c|c|c|c|c|c|}
\hline & Deforestation & $\begin{array}{l}\text { Wood har- } \\
\text { vesting }\end{array}$ & Fire & $\begin{array}{l}\text { Enteric } \\
\text { fermentation }\end{array}$ & $\begin{array}{l}\text { Manure man- } \\
\text { agement }\end{array}$ & Agricultural soils & $\begin{array}{l}\text { Cropland } \\
\text { over histosols }\end{array}$ & Rice & Others \\
\hline $\mathrm{CO}_{2}$ & $\begin{array}{l}\text { Hotspots }^{1} \\
\text { FAOSTAT }^{2} \\
\text { Houghton }^{3} \\
\text { Baccini }^{1}\end{array}$ & $\begin{array}{l}\text { Hotspots }^{4} \\
\text { FAOSTAT }^{5} \\
\text { Houghton }^{4} \\
\text { Baccini }^{4}\end{array}$ & $\begin{array}{l}\text { Hotspots }^{6} \\
\text { FAOSTAT }^{7} \\
\text { EDGAR }^{8} \\
\text { Houghton }^{9} \\
\text { Baccini }^{9}\end{array}$ & & & & $\begin{array}{l}\text { Hotspots }^{10} \\
\text { FAOSTAT }^{11}\end{array}$ & & EDGAR $^{12}$ \\
\hline $\mathrm{CH}_{4}$ & & & $\begin{array}{l}\text { Hotspots }^{13} \\
\text { FAOSTAT }^{14} \\
\text { EDGAR }^{15}\end{array}$ & $\begin{array}{l}\text { Hotspots } \\
\text { FAOSTAT } \\
\text { EDGAR } \\
\text { EPA }\end{array}$ & $\begin{array}{l}\text { Hotspots } \\
\text { FAOSTAT } \\
\text { EDGAR } \\
\text { EPA }\end{array}$ & & & $\begin{array}{l}\text { Hotspots } \\
\text { FAOSTAT } \\
\text { EDGAR } \\
\text { EPA }\end{array}$ & \\
\hline $\mathrm{N}_{2} \mathrm{O}$ & & & $\begin{array}{l}\text { Hotspots }^{13} \\
\text { FAOSTAT }^{14} \\
\text { EDGAR }^{15}\end{array}$ & & $\begin{array}{l}\text { Hotspots } \\
\text { FAOSTAT } \\
\text { EDGAR } \\
\text { EPA }\end{array}$ & $\begin{array}{l}\text { Hotspots }^{16,17} \\
\text { FAOSTAT }^{16,18} \\
\text { EDGAR }^{16,17,19} \\
\text { EPA }^{16,19}\end{array}$ & $\begin{array}{l}\text { Hotspots } \\
\text { FAOSTAT }\end{array}$ & Hotspots & \\
\hline dSOC & & & & & & Hotspots & & Hotspots & \\
\hline
\end{tabular}

forestation, and their Forest Fire and Decay category (5F; Table 3 and Table S1) is used as a proxy for deforestation (Tubiello et al., 2015). Such an approximation leads to underestimations since not all carbon losses from deforestation are necessarily associated with the use of fire (Tubiello et al., 2015). In spite of being net emissions, the deforestation estimates for FAOSTAT were higher than the gross estimates from Hotspots and Baccini. This is partly due to FAOSTAT's inclusion of fire emissions from humid tropical forests (see Sect. 3.2.3), which the other datasets did not have. Baccini's larger estimates of gross deforestation included more carbon pools than the other datasets (i.e. soil, coarse woody debris (CWD), litter). Baccini et al. (2012) reported that their estimated gross and net emissions from tropical deforestation were the same value $\left(4.2 \mathrm{PgCO}_{2} \mathrm{yr}^{-1}\right)$. The difference with Houghton net emissions $\left(5.4 \mathrm{PgCO}_{2} \mathrm{yr}^{-1}\right.$; Fig. 2) corresponds, then, to non-offset carbon emissions from other land uses and activities included in the bookkeeping model: degradation by logging and shifting cultivation, decomposition and decay, and cultivated soils. Houghton tropical net emissions for 2000-2005 are high, but are lower than Houghton reported net estimates in the $1980 \mathrm{~s}\left(7 \mathrm{PgCO}_{2} \mathrm{yr}^{-1}\right.$; Houghton, 1999).

\subsubsection{Forest degradation: wood harvesting and fire emissions}

Forest degradation can be defined in many ways (Simula, 2009), but no single operational definition has been agreed upon by the international community (Herold et al., 2011a). It typically refers to a sustained human-induced loss of carbon stocks within forest that remains forest. In this study, similarly to Federici et al. (2015), we consider degradation to be any annual removal of carbon stocks that does not account for deforestation, without temporal-scale considerations (i.e. time needed for disturbance recovery or time to guarantee a sustained reduction of the biomass). We assessed two major degradation sources: wood harvesting and fire. Soil degradation is poorly captured in many datasets, and mainly focuses on fire in equatorial Asian peatland forests and drained peatlands (Hooijer et al., 2010). A better understanding of the processes and emissions behind forest degradation is key for climate mitigation efforts, not only because forest degradation is a widespread phenomenon (i.e. affects much larger areas than deforestation; Herold et al., 2011b), but also because the lack of knowledge of net carbon effects frequently results in assumptions of carbon neutrality of the affected standing forests, particularly for fire (Houghton et al., 2012; Le Quéré et al., 2014), which likely leads to an underestimation of forest and AFOLU emissions (Brando et al., 2014; Turetsky et al., 2015; Roman-Cuesta et al., 2016). 
Gross emissions from forest degradation were larger than deforestation for the Hotspots, EDGAR, and Baccini datasets, with degradation-to-deforestation ratios of 108,120 , and $128 \%$ respectively. FAOSTAT had degradation emissions of $60 \%$ of the deforestation, partly due to its anomalously low fire contribution (see next section). Houghton et al. (2012) pointed out that global FOLU net fluxes were led by deforestation with a smaller fraction attributable to forest degradation, while the opposite was true for gross emissions (degradation being $267 \%$ of deforestation emissions). This large ratio relates to their inclusion of shifting cultivation under degradation. This is a definition issue, which would not fit the definition of degradation chosen in this study, where a complete forest cover loss would represent deforestation and not degradation.

\section{Fire}

Fire led the gross forest degradation emissions in the tropics in 2000-2005 (Fig. 2): 2 (1.1-2.7), 0.2, 3.4, 2.9 $\mathrm{PgCO}_{2}$ eq. $\mathrm{yr}^{-1}$ for the Hotspots, FAOSTAT, EDGAR, and Baccini datasets respectively; Fig. 2). The Hotspots estimates are conservative compared to Van der Werf et al. (2010)'s global emissions of $7.7 \mathrm{PgCO}_{2}$ eq. $\mathrm{yr}^{-1}$ for 2002-2007, due to the removal of $\mathrm{CO}_{2}$ from deforestation fires (to avoid double counting with deforestation emissions), the exclusion of fires in grasslands and agricultural residues, and Hotspots' smaller study area. FAOSTAT and EDGAR had the lowest and the highest fire values. The lowest values in FAOSTAT relate to omissions that are currently in the process of being corrected (S. Rossi, personal communication, 2016): (1) the complete exclusion of $\mathrm{CO}_{2}$ from fire in humid tropical forests and other forests (Table 3, Table S1), which FAOSTAT relocated as net forest conversion emissions, partly explains their larger deforestation values (FAOSTAT kept $\mathrm{CH}_{4}$ and $\mathrm{N}_{2} \mathrm{O}$ for fire in humid tropical forests and other forests), and (2) the use of default parameters for fuel in peats from the IPCC 2006 guidelines instead of the new IPCC Wetland Supplement, because they offer considerably higher values (Rossi et al., 2016). Moreover, FAOSTAT uses GFED3.0 burned area (Giglio et al., 2010) in their estimates while the other datasets use GFED3.0 emissions (Van der Werf et al., 2010). EDGAR fire emissions were the largest most likely because they included decay. Their dataset considers some undefined forest fires (5A) and wetland/peatland fires and decay (5D; Table 3; Table S1). Peatland decay probably explains EDGAR's larger emissions in Asia, while we assume that EDGAR's highest fire emissions for CS America might respond to deforestation fires which were not included in the Hotspots to avoid double counting with deforestation, and relocated in FAOSTAT to deforestation emissions (Fig. 3, Table 3). The Hotspots dataset showed higher gross fire emissions for Africa due to the inclusion of woodland fire, which EDGAR and FAOSTAT probably excluded. Baccini et al. (2012)'s fire emissions:
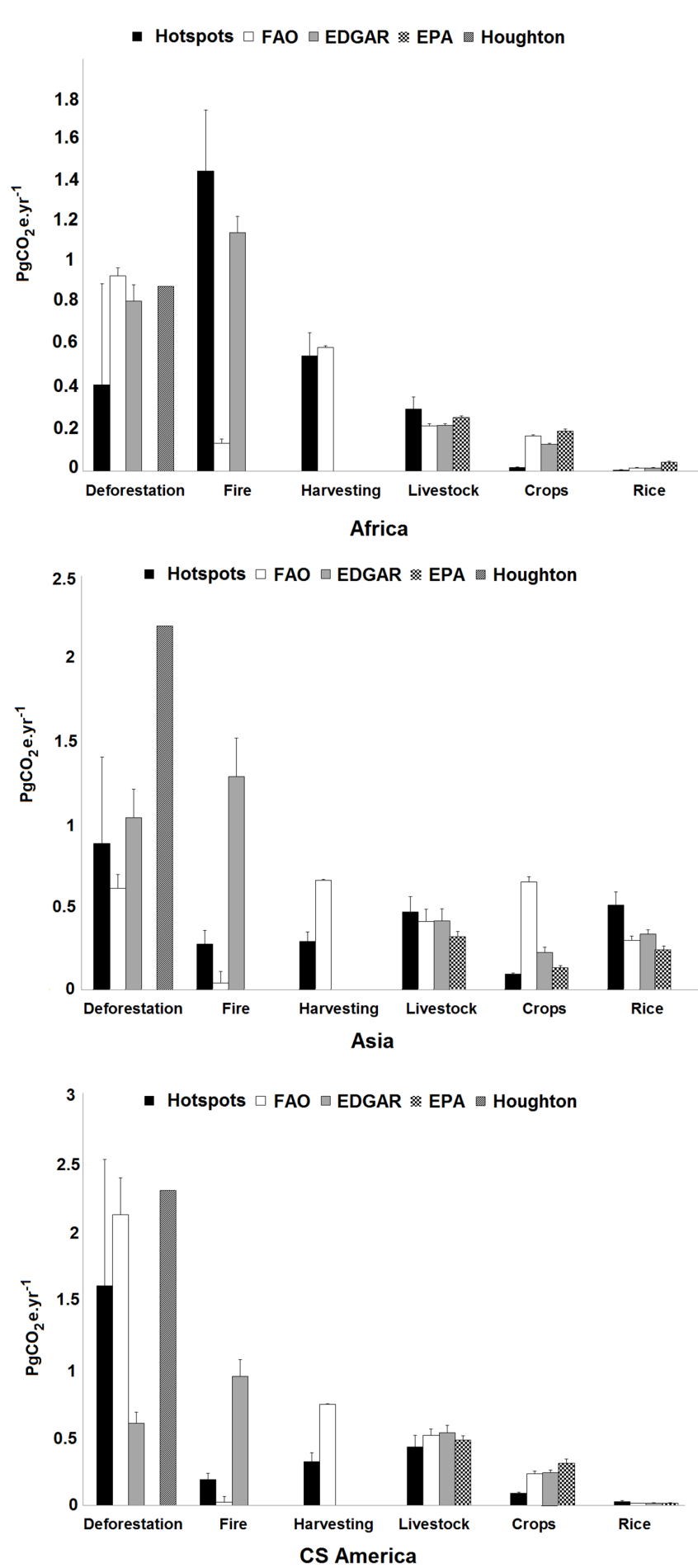

Figure 3. Continental disaggregated emissions for the individual emission sources $\left(\mathrm{PgCO}_{2}\right.$ eq. $\left.\mathrm{yr}^{-1}\right)$. Bars indicate uncertainty estimates for the Hotspots dataset ( $1 \sigma$ from mean). No uncertainty estimates are available for the other datasets. Houghton data are net land use emissions (Forestry and Other Land Use) rather than deforestation and are offered for visual comparison only. EPA covers agricultural emissions only (livestock, crops, and rice) and no forest emissions. 
2.9 $\mathrm{Pg} \mathrm{CO}_{2}$ eq. $\mathrm{yr}^{-1}$ (2000-2010) derived from Houghton's bookkeeping, but it is unclear how these emissions were estimated.

In spite of the importance of fire as a degradation source, this variable is frequently incompletely included, either through unaccounted gases (i.e. $\mathrm{CH}_{4}$ and $\mathrm{N}_{2} \mathrm{O}$ are excluded in the carbon community but their omission represent 17 $34 \%$ of the gross $\mathrm{CO}_{2}$ fire emissions; Valentini et al., 2014; Roman-Cuesta et al., 2016) or to unaccounted components (i.e. fires in tropical temperate forests such as conifers or dry forests such as woodlands are frequently excluded; Houghton et al., 2012). Unaccounted fire emissions are also derived from methodological choices (i.e. only interannual fire anomalies are considered; Le Quéré et al., 2014), from poor satellite observations such as understory fires in humid closed canopy forests; Alencar et al., 2006, 2012; Morton et al., 2013), or satellite fire omissions in certain regions (i.e. high Andean fires; Bradley and Millington, 2006; Oliveras et al., 2014). Other omissions relate to the current exclusion of non-Asian peatland fires (i.e. American tropical montane cloud forest peatland fires; Asbjornsen et al., 2005; RomanCuesta et al., 2011; Oliveras et al., 2013; Turetsky et al., 2015).

Fire suffers, moreover, from a series of assumptions that do not apply so easily to other types of degradation: (1) assuming a non-human nature of the fires (deforestation fire vs. wildfires), which in tropical areas contrasts with multiple citations referring to the $90 \%$ human causality of fires (Cochrane et al., 1999; Roman-Cuesta et al., 2003; Alencar et al., 2006; Van der Werf et al., 2010); (2) assuming force majeure conditions that lead to non-controllable fires due to extreme climate conditions, which frequently result in incomplete assessment and reporting of emissions. This assumption contrasts with research on how human activities have seriously increased fire risk and spread in the tropics (Uhl and Kauffman, 1990; Laurance and Williamson, 2001; RomanCuesta et al., 2003; Hooijer et al., 2010), and clearly expose how most of the fires in the humid tropics would not occur in the absence of human influences over the landscape (RomanCuesta et al., 2003). (3) We assuming carbon neutrality and full biomass recovery after fire in standing forests. This is a generous assumption that contrasts with numerous studies on tropical forest die-back following fire events in non-fire adapted humid tropical forests (Cochrane et al., 1999; Barlow and Peres, 2008; Roman-Cuesta et al., 2011; Brando et al., 2012; Oliveras et al., 2013; Balch et al., 2015). All these phenomena cast doubts on the robustness of these assumptions and call for a much more comprehensive inclusion of fire emissions into forest degradation budgets.

\section{Wood harvesting}

There is not a unique way to estimate wood harvesting emissions as exposed in the guidelines for harvested wood products of the IPCC (IPCC, 2006). Assumptions regard- ing the final use of the wood products, decay times, substitution effects, international destination of the products, and time needed for forests to recover their lost wood can fully change the emission budgets. In our study, woodharvesting emissions were $1.2(0.7-1.6), 2.0,1.7 \mathrm{PgCO}_{2} \mathrm{yr}^{-1}$ for the Hotspots, FAOSTAT, and Baccini data respectively (Tables 3, S1). Harvested wood products are derived from FAO country reports (i.e. FAOSTAT forest products). All datasets included fuel wood and industrial roundwood (Tables 3, S1). EDGAR excluded fuelwood from the AFOLU budget and placed it instead into the energy budget (EDGAR, 2012), which explains its absence in Fig. 2. Wood-harvesting emissions were larger in FAOSTAT than in the Hotspots data (Fig. 2), partly due to the inclusion of some extra categories of fuels (i.e. charcoal and residues) that were not included in the Hotspots database (Tables 3, S1). Charcoal represents $26 \%$ of the total wood-harvesting emissions in FAOSTAT. Differences on wood harvesting affected Asia and CS America more (where the Hotspots data were half of the FAOSTAT data), while Africa presented almost identical values (Fig. 3). The reasons for these continental differences are unclear. Baccini's high emissions for wood harvesting could partly be related to their inclusion of extra biomass due to felling damages (i.e. $20-67 \%$ of the AGB is damaged, and $20 \%$ are left dead in BGB; Houghton, 1999).

\subsubsection{Livestock}

Livestock emissions were the most homogeneous among the emissions sources (Fig. 2) with estimates of $1.2(0.8-1.5)$, $1.1,1.2,1.1 \mathrm{PgCO}_{2}$ eq. $\mathrm{yr}^{-1}$ for the Hotspots, FAOSTAT, EDGAR, and EPA respectively, in range with the estimates in the AR5 (Fig 11.5 in Smith et al., 2014). Values were similar in spite of being derived from different tiers (i.e. Tier 3 for Herrero et al. (2013), Tier 1 for FAOSTAT and EDGAR. EPA used Tier 3 but for incomplete data series, otherwise Tier 1 was applied, USEPA, 2013). All datasets included enteric fermentation $\left(\mathrm{CH}_{4}\right)$ and manure management $\left(\mathrm{N}_{2} \mathrm{O}\right.$, $\mathrm{CH}_{4}$ ). All of them relied on FAO data for livestock heads, although they used different years (i.e. 2000 for Herrero et al. (2013) data in the Hotspots, and 2007-2010 for EDGAR). From a continental perspective, FAOSTAT and EDGAR estimates were the closest while the Hotspots and EPA estimates were less similar. The Hotspots showed higher emissions for Africa and Asia and lower emissions for CS America compared to the other three datasets. Divergences likely relate to different tiers. CS America and Asia showed the highest values, with Africa following closely (Fig. 3), similar to what is reported in the AR5 (Smith et al., 2014). Globally, livestock farming is the largest source of $\mathrm{CH}_{4}$ emissions, with threequarters of the emissions coming from developing countries, particularly Asia (USEPA, 2013, Tubiello et al., 2014). Three out of the top five emitting countries are in the tropics: Pakistan, India, and Brazil (USEPA, 2013) and, while Asia hosts 
the largest livestock emissions, the fastest growing trends in 2011 correspond to Africa (Tubiello et al., 2014).

\subsubsection{Cropland emissions}

The estimates of cropland emissions reached values of 0.18 (0.16-0.19), 0.56, 0.6, and $0.64 \mathrm{Pg} \mathrm{CO}_{2}$ eq. $\mathrm{yr}^{-1}$ for the Hotspots, FAO, EDGAR, and EPA datasets respectively, for $\mathrm{N}_{2} \mathrm{O}$ and $\mathrm{CO}_{2}$ from changes in soil organic carbon content. Cropland soil emissions $\left(\mathrm{N}_{2} \mathrm{O}\right.$ and soil organic carbon stocks $\left(\mathrm{CO}_{2}\right)$ heavily depend on land management practices (i.e. tillage, fertilization, and irrigation practices) and climate (Crowther et al., 2015). We chose exactly the same land practices in all datasets to allow comparisons (Tables 3, S1). For this reason, we excluded $\mathrm{N}_{2} \mathrm{O}$ emissions from grassland soils, drainage of organic soils, and restoration of degraded lands (Table 3). This restrictions resulted in lower emissions than those estimated for cropland soils in the AR5 (Fig. 11.5 in Smith et al., 2014). The Hotspots and EPA showed the lowest and the highest estimates (Figs. 2, 3). With the exception of the Hotspots, the other datasets agreed well at the tropical scale, with FAOSTAT and EDGAR being almost identical, also at continental scales. EPA disagreed more than the other datasets at the continental scale, with underestimations for Asia that were probably related to the parameterization of its emission model. All three datasets used FAO activity data, and for EDGAR and FAOSTAT the same emission factors must have been used. The Hotspots showed anomalously low emissions partly because it only included six major crop types (maize, soya, sorghum, wheat, barley, and millet) for which the emission model (DAYCENT) counted on reliable parametrization (S. Ogle, personal communication, 2016). Emissions from other important crops in the tropics (e.g. sugar cane, tobacco, tea) were excluded, as well as emissions from croplands in organic soils, due to model constraints.

\subsubsection{Peatland drainage for agriculture}

Estimates of drained peatlands (mainly for agricultural purposes) suggest large omissions in the Hotspots database with emissions 1 order of magnitude lower $\left(28 \mathrm{TgCO}_{2}\right.$ eq. $\left.\mathrm{yr}^{-1}\right)$ than FAOSTAT (ca. $500 \mathrm{TgCO}_{2}$ eq. $\mathrm{yr}^{-1}$ ) and 1 order of magnitude lower than the values reported for peatland drainage in Asia alone (Hooijer et al., 2010; 355$855 \mathrm{TgCO}_{2}$ eq. $\mathrm{yr}^{-1}$ ). The lower values in the Hotspots dataset relate to much smaller agricultural areas with histosols ( 0.4 mill ha) than those reported by FAOSTAT for the same countries $(7 \mathrm{mill}$ ha). This area difference is partly due to the methodological approach used by Ogle et al. (2013) in which only six major crop covers are considered: maize, wheat, sorghum, soya beans, millet, and barley, and partly to the unmatching spatial scales of histosols and croplands (i.e. $1 \mathrm{~km}$ for histosols and $50 \mathrm{~km}$ for croplands) which result in underestimations of the final area.

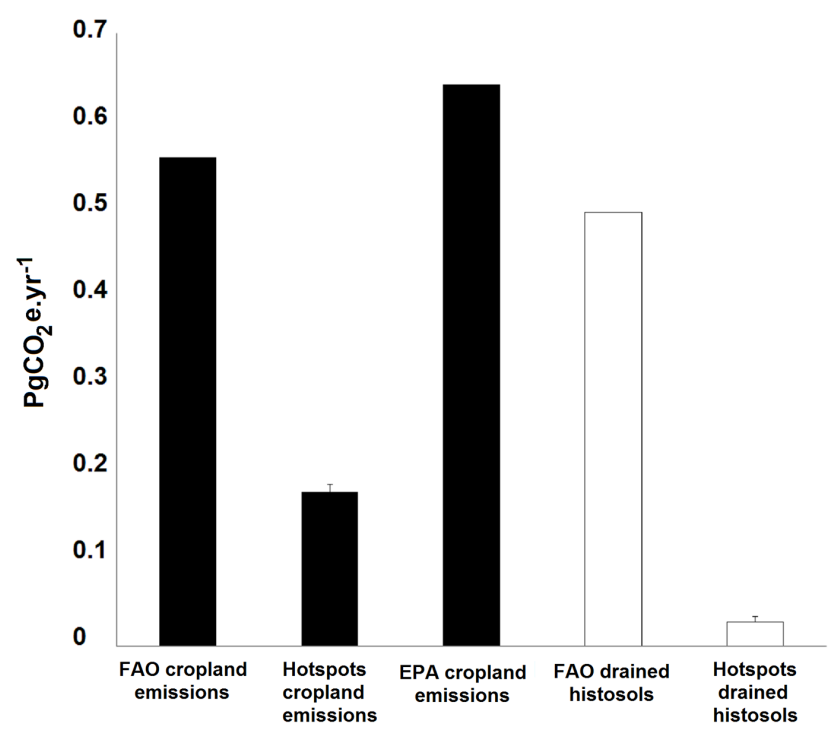

Figure 4. Disaggregation of cropland soil emissions from drained peatlands for datasets with available data: FAOSTAT and Hotspots. Organic soils are excluded in EPA cropland emissions.

\subsubsection{Paddy rice}

When paddy fields are flooded, decomposition of organic material gradually depletes the oxygen present in the soil and floodwater, causing anaerobic conditions in the soil that favour methanogenic bacteria that produce $\mathrm{CH}_{4}$. Some of this $\mathrm{CH}_{4}$ is dissolved in the floodwater, but the remainder is released to the atmosphere, primarily through the rice plants themselves. Net emission estimates for paddy rice were 0.55 (0.4-0.833), 0.33, 0.37, 0.30 $\mathrm{Pg} \mathrm{CO}_{2}$ eq. $\mathrm{yr}^{-1}$ for the Hotspots, FAOSTAT, EDGAR, and EPA datasets respectively. The Hotspots showed the highest emissions (Fig. 2), but only in Asia (Fig. 3). Part of the reason behind these differences refers to the final gases estimated in Li et al. (2013) which included $\mathrm{CH}_{4}, \mathrm{~N}_{2} \mathrm{O}$ and decomposition of soil organic carbon (SOC; $\mathrm{CO}_{2}$; Table $3, \mathrm{~S} 1$ ), while the others only focused on $\mathrm{CH}_{4}$. In $\mathrm{Li}$ et al. (2013)'s estimates, $\mathrm{N}_{2} \mathrm{O}$ were $48 \%$ of the $\mathrm{CH}_{4}$ emissions, explaining the doubled emissions in the Hotspots database. SOC was a sink, with $-0.076 \mathrm{PgCO}_{2} \mathrm{yr}^{-1}$.

Based on the explanations above, Table 4 points out the likely least reliable emission sources for each dataset considering disagreements among emission estimates due to biased/divergent/incomplete definitions and methods. Houghton's sinks are suggested as least reliable since they suffer from compatibility issued with IPCC guidance and exclude sinks from non-disturbed areas and forests undergoing disturbances other than wood harvesting or recovery from shifting cultivation (Grassi and Dentener, 2015; Federici et al., 2016). 
Table 4. Identification of the least reliable emission source $(\mathrm{x})$ for each dataset considering disagreements among emission estimates due to biased/divergent/incomplete definitions and methods.

\begin{tabular}{|c|c|c|c|c|c|c|c|}
\hline & Hotspots & FAOSTAT & EDGAR & Houghton* & Baccini & EPA & AR5* \\
\hline Deforestation & & & $\mathrm{x}$ & & $\mathrm{x}$ & & \\
\hline Fire & & $\mathrm{x}$ & & & $\mathrm{x}$ & & $\mathrm{x}$ \\
\hline $\begin{array}{l}\text { Wood harvesting } \\
\text { Livestock }\end{array}$ & & & $\mathrm{x}$ & & & & \\
\hline $\begin{array}{l}\text { Cropland } \\
\text { Paddy rice }\end{array}$ & $\mathrm{x}$ & & & & & $\mathrm{x}$ & \\
\hline Peatland & $\mathrm{x}$ & & & & & $\mathrm{x}$ & \\
\hline Forest sinks & & & & $x$ & & & $x$ \\
\hline
\end{tabular}

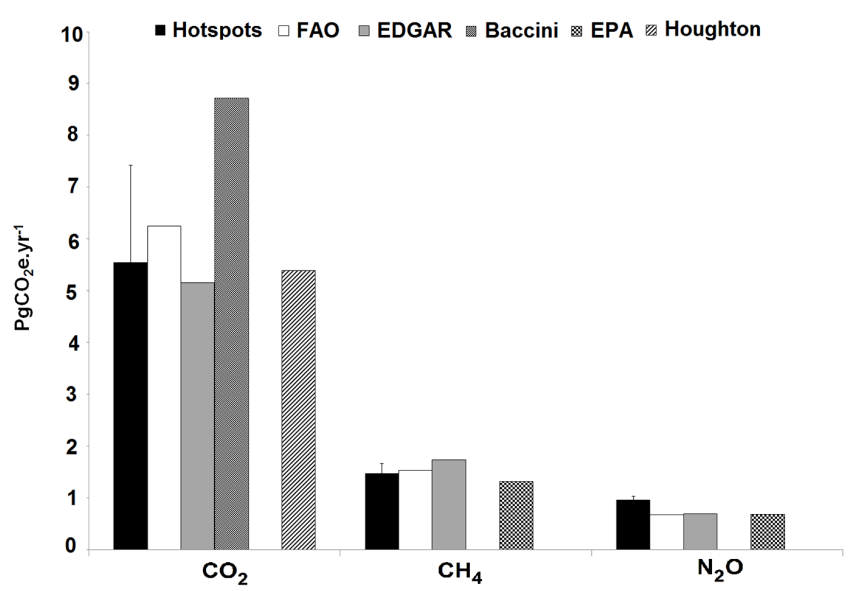

Figure 5. Contribution of the different AFOLU greenhouse gases $\left(\mathrm{CO}_{2}, \mathrm{CH}_{4}, \mathrm{~N}_{2} \mathrm{O}\right)$ from the different datasets. Uncertainties are only provided in the Hotspots dataset ( $1 \sigma$ from mean). EPA data do not include forest emissions. Houghton and Baccini are FOLU (Forestry and Other Land Use) $\mathrm{CO}_{2}$-only datasets and do not include agricultural emissions. Houghton offers net emissions while Baccini data are gross emissions for deforestation, fire, and wood harvesting (Baccini et al., 2012).

\subsection{Differences in the relative contribution of greenhouse gases $\left(\mathrm{CO}_{2}, \mathrm{CH}_{4}, \mathrm{~N}_{2} \mathrm{O}\right)$}

GHG emissions $\left(\mathrm{CO}_{2}, \mathrm{CH}_{4}, \mathrm{~N}_{2} \mathrm{O}\right)$ showed good agreement at the sectoral level (FOLU and agriculture; Fig. 5), which disappeared at the disaggregated level (Fig. 6). $\mathrm{CO}_{2}$ showed the largest disagreements between datasets and gases, led by forests emissions and particularly fire. SOC accumulation was reported in the Hotspots data (Li et al., 2013) but it is uncertain if it is included in the other datasets.

Non- $\mathrm{CO}_{2}$ emissions showed lower variability than $\mathrm{CO}_{2}$ (Fig. 6). Livestock-led $\mathrm{CH}_{4}$ emissions and showed the largest differences between datasets, with the Hotspots data (Herrero et al., 2013) having the lowest $\mathrm{CH}_{4}$ emissions, which were compensated with larger $\mathrm{N}_{2} \mathrm{O}$ than the other datasets (Fig. 6b,c). At a global level, wetlands dominate natural $\mathrm{CH}_{4}$ emissions, while agriculture and fossil fuels represent two-thirds of all human emissions, with smaller contributions coming from biomass burning, the oceans, and termites (Montzka et al., 2011). Non- $\mathrm{CO}_{2}$ fire emissions were quite similar among datasets, confirming that FAOSTAT omissions were $\mathrm{CO}_{2}$ related (see Sect. 3.2.3). Thus, as exposed in FAOSTAT metadata, only $\mathrm{N}_{2} \mathrm{O}$ and $\mathrm{CH}_{4}$ are considered in forest fires, excluding $\mathrm{CO}_{2}$ from aboveground biomass. As expected, $\mathrm{N}_{2} \mathrm{O}$ emissions in crops showed large differences, with the Hotspots having the lowest values (3 times lower). Rice $\mathrm{N}_{2} \mathrm{O}$ emissions were omitted in all datasets except the Hotspots (Li et al., 2013), which also included SOC.

The importance of multi-gas assessments relates to their role in climate change mitigation due to their radiative forcing (RF), understood as a measure of the warming strength of different agents (gases and not gases) in causing global warming $\left(\mathrm{W} \mathrm{m}^{-2}\right) . \mathrm{CO}_{2}$ is the most abundant $(400 \mathrm{ppm}$ in 2015) and longest living gas which makes it the leading force of global warming (Anderson, 2012). Non- $\mathrm{CO}_{2}$ GHGs are less abundant in the atmosphere (1774 and $319 \mathrm{ppb}$ for $\mathrm{CH}_{4}$ and $\mathrm{N}_{2} \mathrm{O}$ in 2005 respectively) but have larger warming potentials ( $\times 28$ for $\mathrm{CH}_{4}$ and $\times 265$ for $\mathrm{N}_{2} \mathrm{O}$; AR4) but shorter lifetimes than $\mathrm{CO}_{2}(\sim 9$ and $\sim 120$ years respectively). In spite of their shorter lifespans they offer an additional opportunity to mitigate climate change (Montzka et al., 2011) partly because they play a role in atmospheric chemistry that contributes to short-term warming (Montzka et al., 2011) and partly because their presence counteracts $\mathrm{CO}_{2}$ terrestrial sinks (Tian et al., 2016).

\subsection{Country-level emissions}

Country comparisons showed poor agreement among datasets for all the emission sectors, particularly for the largest emitters (i.e. Brazil, Argentina, India, Indonesia; Figs. 7, 8). Forests led the AFOLU disagreements (as observed by the similarity of Fig. 7a, b). From a continental perspective, Central and South America had more countries with high levels of disagreement, suggesting a need for further data research. 


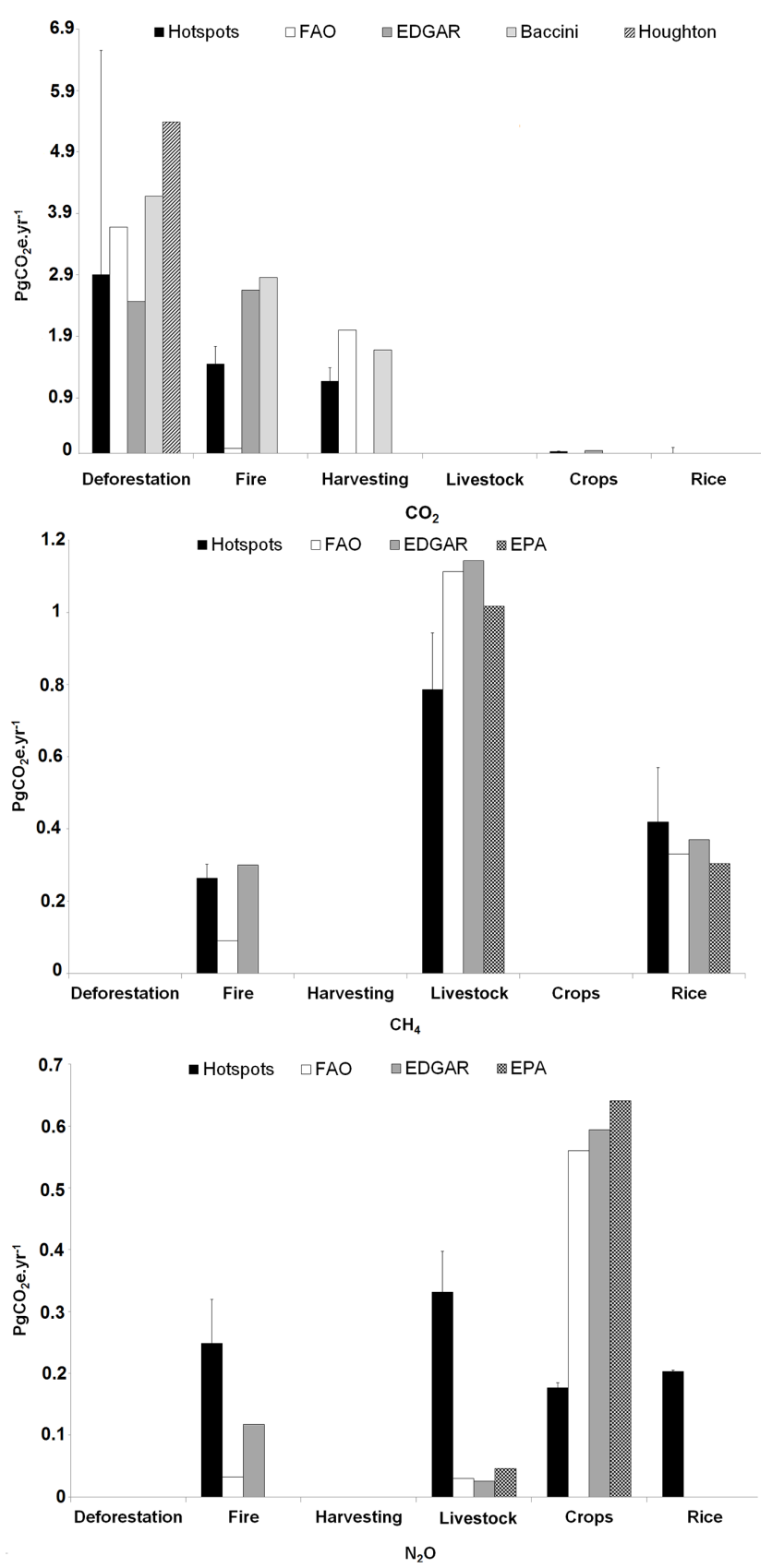

Figure 6. GHG emission contribution $\left(\mathrm{CO}_{2}, \mathrm{CH}_{4}\right.$, and $\left.\mathrm{N}_{2} \mathrm{O}\right)$ of the leading AFOLU emission sources. Bars indicate uncertainty estimates ( $1 \sigma$ from mean). Uncertainties are only provided in the Hotspots dataset. No uncertainty estimates are available for the other datasets. EPA data do not include forest emissions. Houghton and Baccini are FOLU (Forestry and Other Land Use) $\mathrm{CO}_{2}$-only datasets and do not include agricultural emissions. Houghton offers net emissions while Baccini data are gross emissions for deforestation, fire, and wood harvesting (Baccini et al., 2012).

\subsection{Some reflections on the datasets}

\subsubsection{Original goals}

Different datasets were developed for different purposes that have influenced the methods and approaches chosen to estimate their land use GHGs. Thus, EDGAR was created with an air pollution focus making its land emissions weaker. In contrast, FAOSTAT carries FAO's focus on land, particularly agriculture (data available since the 60s), with forest data added later through the FRA assessments (1990, 2005, 2010, 2015). The "Hotspot" database was created to identify the areas with the largest land use emissions in the tropics (emissions hotspots), while Houghton's accent is on historical LULUCF emission trends (since 1850). EPA concentrates on industrial, energy, and agricultural emissions. Forests are excluded with an interest on human health and mitigation. Moreover, due to its long existence, several datasets rely on FAOSTAT long-term agricultural data, which is probably the reason behind the higher homogeneity of agricultural emission estimates (i.e. crops, rice, and livestock among datasets). FAOSTAT forest emissions use FRA data, which get updated every 5 years. Different FRA versions strongly influence forest emission estimates which makes it important to acknowledge the FRA version used when contrasting FAOSTAT emissions and when comparing estimates (i.e. differences up to $22 \%$ between the forest sink estimates using FRA2015 and FRA2010 have been reported by Federici et al., 2015). Similarly, official updates of Houghton's bookkeeping TRENDS data, as well as researchers' self-tuned versions of his model, result in emission differences that are difficult to track.

\subsection{IPCC guidelines and guidance}

Under the UNFCCC, countries are requested to use the latest IPCC AFOLU guidelines to estimate their GHG emissions (i.e. IPCC, 2006, 2003 for developed and developing countries respectively). The use of different guidelines, tiers, and approaches influences the final emission estimates. Compliance with IPCC has two main consequences: (1) the total area selected to report emissions and (2) the choice of land use over land cover. In the first case, under IPCC guidance, the total area selected to report emissions would include all the land under human influence (the managed land concept, which includes areas under active and non-active management). Houghton's bookkeeping model and the carbon modelling community in general do not comply well with the managed land concept, resulting in different net emissions from forest land uses and land use changes (LULUCF) than IPCC compliant country emissions (Grassi and Dentener, 2015; Federici et al., 2016). In the second case, the selection of land uses instead of land covers has partly been behind the recent controversy between FAO and the Global Forest Watch's reported estimates on deforestation 

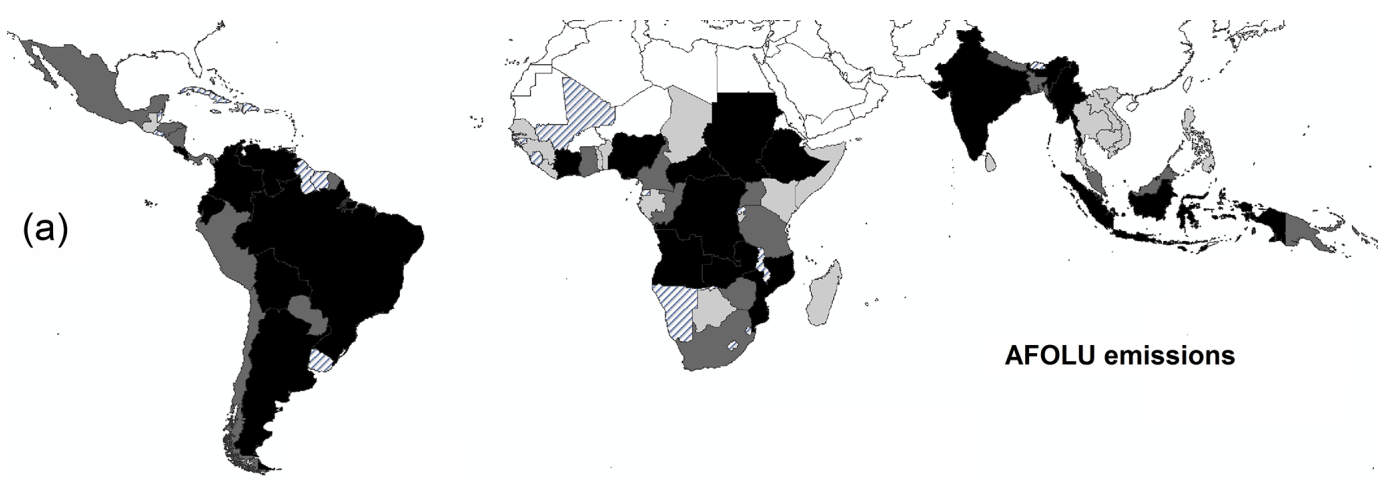

AFOLU emissions
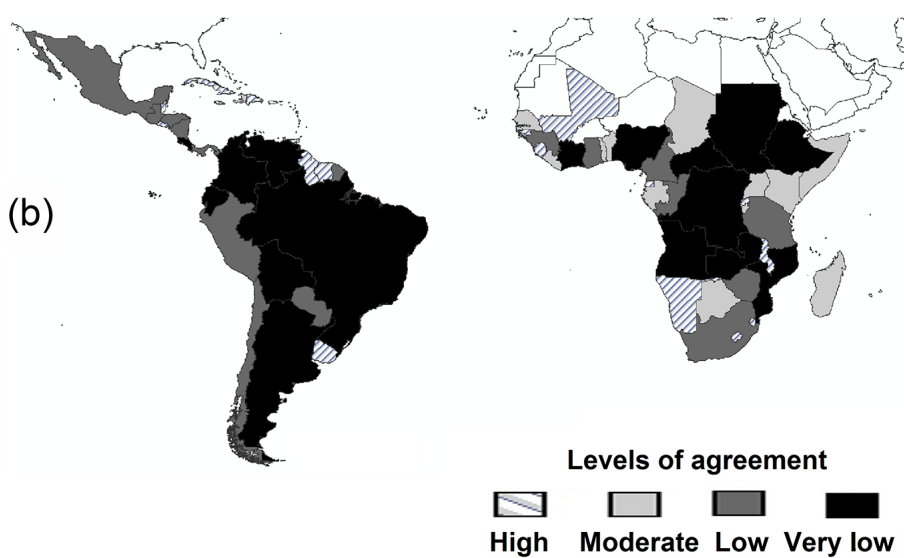

Figure 7. Country-level agreement for (a) AFOLU and (b) forest emissions for the FAOSTAT, EDGAR, and Hotspots datasets, The categories of agreement are percentiles of the standard deviations which represent a measure of data variability. High agreement corresponds to low data variability ( $\leq 25$ th percentile), moderate agreement to 25 th-50th percentiles, low agreement to 50th-75th percentiles and very low agreement to $\geq 75$ th percentile, which corresponds to very high data variability.

trends (Holmgren, 2016). Estimates of deforestation that rely on land cover are higher than those using land use, since forest losses under forest land uses that remain forest land use are not considered deforestation (i.e. logged areas will regrow). In our analysis, FAO and Houghton rely on land use for deforestation, while Hotspots and EDGAR rely on land cover. FAOSTAT and Hotspots rely on the 2006 IPCC guidelines for National Greenhouse Gas Inventories (IPCC, 2006). FAOSTAT uses Tier 1 and standard emission factors, while Hotspots uses a combination of tiers (Tier 3 for all emissions except wood harvesting and cropland emissions over histosols that rely on Tier 1). EDGAR reports the use of 2006 IPCC guidelines for the selection of the emission factors but some of their methodological approaches are not always consistent with IPCC guidelines (i.e. deforestation expressed as the decay of burned forests, wood harvesting is part of the energy sector, agricultural energy balances are included in the AFOLU budget). EPA methods are reported to be consistent with IPCC guidelines and guidance, with Tier 1 methodologies used to fill in missing or unavailable data (USEPA, 2013).

\section{Conclusions}

The Paris Agreement (COP21) counts on the Intended Nationally Determined Contributions (INDCs) as the core of its negotiations to fight climate change. As of March 2016, 188 countries had submitted their INDCs under the UNFCC (FAO, 2016) with agriculture (crops, livestock, fishery, and aquaculture) and forests as prominent features in meeting the countries' mitigation and adaptation goals ( $86 \%$ percent of the countries include AFOLU measures in their INDCs, placing it second after the energy sector; FAO, 2016). However, there exists large variability in the way countries present their mitigation goals, and quantified sector-specific targets are rare (FAO, 2016). Variability relates not only to the lack of a standardized way of reporting mitigation commitments under the INDCs, but also to uncertainties and gaps in the AFOLU data. The Paris Agreement relies on a 5-year cycle stock-taking process to enhance mitigation ambition, and to keep close to the $2{ }^{\circ} \mathrm{C}$ target. To be effective and efficient, stock-taking needs to be robust, transparent, and to have certain numbers (at least with known uncertainties). This is true both for national emission reports and INDCs, but also for 

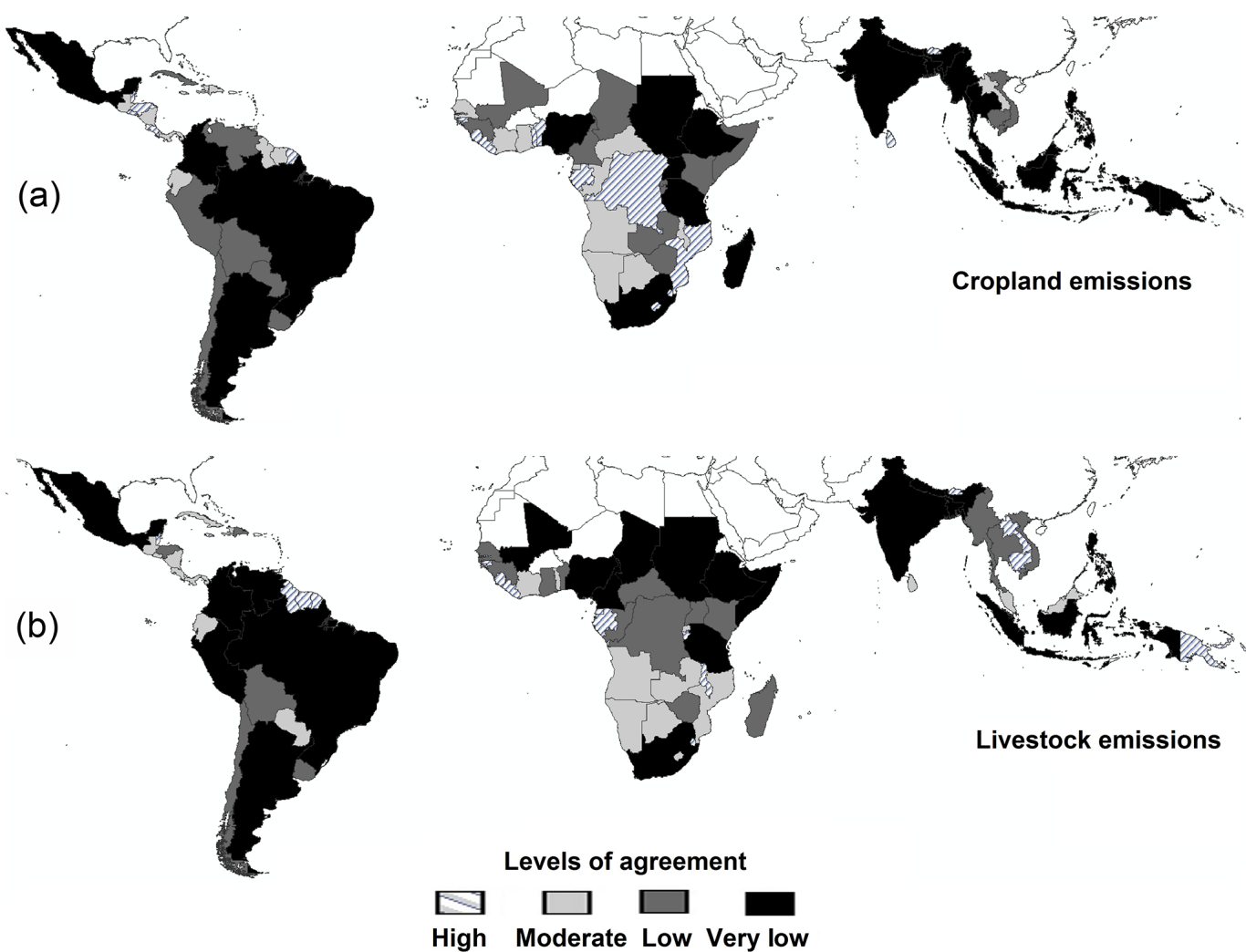

Figure 8. Country-level agreement for (a) cropland and (b) livestock emissions for the FAOSTAT, EDGAR, and Hotspots databases. The categories of agreement are percentiles of the standard deviations which represent a measure of data variability. High agreement corresponds to low data variability ( $\leq 25$ th percentile), moderate agreement to 25 th-50th percentiles, low agreement to 50th-75th percentiles and very low agreement to $\geq 75$ th, which corresponds to very high data variability.

the global datasets which can be used to review the feasibility of countries' mitigation claims, and the real space for further mitigation commitments. Here, we have compared the gross AFOLU emissions of six datasets to search for disagreements, gaps, and uncertainties, focusing on the tropical region. Conclusions depend on the spatial scale.

- Data aggregation offers more homogeneous emission estimates than disaggregated data (i.e. continental level, gas level, emission source level).

- Forest emissions are the most uncertain of the AFOLU sector, with deforestation having the highest uncertainties.

- Agricultural emissions, particularly livestock, are the most homogeneous of the AFOLU emissions.

- Forest degradation, both fire and wood harvesting, show the largest variabilities among databases.

- $\mathrm{CO}_{2}$ is the gas with longer-term influence in climate change trends, but it remains the most uncertain among the AFOLU gases and the most variable, in absolute value, among datasets (Fig. 5) Fire leads this variability (Fig. 6).
- Among the non- $\mathrm{CO}_{2}$ gases, $\mathrm{N}_{2} \mathrm{O}$ showed the most variable emission estimates, in absolute value, in all the emission sources and for all the datasets (Fig. 6).

- Emissions from histosols/peatlands remain incomplete or fully omitted in most datasets.

For the country and continental scales, we found the following.

- Large emitters show the highest levels of data disagreement in the tropics, enhancing the need for data improvement to guarantee effective mitigation action.

- Forest lead the emission disagreement in the total AFOLU emissions.

- Central and South America showed the largest continental disagreements on emission data for all the land sectors. 


\subsection{Next steps}

Enhancing dialogue between the carbon and the AFOLU research communities

Research run by the carbon community is pivotal for AFOLU assessments and, while these two research communities overlap, they do not focus on exactly the same topics. The carbon community works with $\mathrm{CO}_{2}$ emissions only, fully excluding non- $\mathrm{CO}_{2}$ gases, particularly $\mathrm{N}_{2} \mathrm{O}$. It moreover rather focuses on forests and associated land use changes, excluding emissions from agriculture. The AFOLU community has, contrarily, a multi-gas approach $\left(\mathrm{CO}_{2}, \mathrm{CH}_{4}, \mathrm{~N}_{2} \mathrm{O}\right)$ and includes emissions from both forests and agriculture. For these reasons, estimates of the carbon community cannot be considered AFOLU estimates, and confusion appears in the IPCC's AR5 with an incorrect AFOLU labelling (Table 11.1, Fig. S2). There is great potential for these two communities to cooperate but further dialogue is needed to promote closer and more coordinated action. Future steps might include the adoption of the managed land concept by the carbon community and ways to include legacy emissions by the AFOLU community.

\subsection{Improving data quality}

The quality of the reported AFOLU emissions can be assessed through the UNFCCC principles: completeness, comparability, consistency, accuracy, and transparency, which can help navigate the improvements of national monitoring systems. From these principles, the reviewed datasets performed well in consistency (they applied similar methods and assumptions over time, with the exception of Hotspots that did not include temporal data). Transparency was excellent for FAOSTAT with well elaborated and publicly available metadata linked to their offered data, while EDGAR performed poorly due to insufficient metadata. Improving transparency requires an urgent call for future action. Improving accuracy and uncertainty also requires urgent action. Thus, in spite of their importance in fully understanding the emission trends and dynamics, only Houghton and the Hotspots provided uncertainties. FAO offered uncertainties as a percent value for each emission source. Completeness and omissions are also urgent tasks because all datasets are incomplete, i.e. missing pools, missing gases (Table 1), and omissions affect all datasets. Complete emission reporting should consider the importance of the following:

- forest soil $\mathrm{CO}_{2}$ and $\mathrm{N}_{2} \mathrm{O}$ emissions (Werner et al., 2007 ; i.e. $\mathrm{N}_{2} \mathrm{O}$ tropical forest soil emissions of $0.7 \mathrm{Pg} \mathrm{CO}_{2}$ eq. $\mathrm{yr}^{-1}$ );

- emissions from $\mathrm{CH}_{4}$ and $\mathrm{N}_{2} \mathrm{O}$ from drained peatland soils, and from wetlands over managed land (i.e. conservation);
- all forest fire types (i.e. temperate conifers and woodlands; understory fires over humid closed canopy forests (Alencar et al., 2006; Morton et al., 2013; i.e. 85500 $\mathrm{km}^{2}, 1999-2010$ in southern Brazilian Amazon); fire emissions over peatland soils and peatland forests out of Asia (Román-Cuesta et al., 2011; Oliveras et al., 2014; i.e. 4-8 $\mathrm{TgCO}_{2}$ eq., 1982-1999, for the tropical high Andes from Venezuela to Bolivia);

- $\mathrm{CO}_{2}$ emissions from other components of wood harvesting other than fuel and industrial roundwood (i.e. charcoal, residues);

- $\mathrm{CO}_{2}$ emissions from tree biomass loss due to fragmentation (Numata et al., 2010; Pütz et al., 2014; i.e. $\left.0.2 \mathrm{Pg} \mathrm{C} \mathrm{yr}^{-1}\right)$;

- $\mathrm{CO}_{2}$ due to decomposition and decay of forests under extreme events such as hurricanes (Read and Lawrence, 2003; Negron-Juarez et al., 2010; i.e. in the 2005 convective storm, the Amazon basin suffered from an estimated tree mortality of $542 \pm 121$ million trees), intense droughts (Phillips et al., 2009, 2010; Brienen et al., 2015; i.e. the 2005 Amazonian drought resulted in $1.2-1.6 \mathrm{PgC}$ emissions and the atmosphere has yet to see $13.9 \mathrm{PgCO}_{2}(3.8 \mathrm{PgC})$ of the Amazon necromass carbon produced since 1983).

Further suggestions on improving data gaps and knowledge for the AFOLU sector have been reported by Smith et al. (2014), Houghton et al. (2012), USEPA (2013), and Sist et al. (2015), with a focus on soil data and crop production systems, as well as an improved understanding of the mitigation potentials, costs, and consequences of land use mitigation options.

\section{Data availability}

Data will be available at my website: https://www.wur.nl/en/ project/Agriculture_Forestry_and_Other_Land_Use.htm.

\section{The Supplement related to this article is available online at doi:10.5194/bg-13-5799-2016-supplement.}

Author contributions. Rosa Maria Roman-Cuesta, Mariana C. Rufino, and Martin Herold designed the study. Stephen Ogle and Benjamin Poulter provided data and ran quality controls of the data. Rosa Maria Roman-Cuesta, Mariana C. Rufino, Martin Herold, Klaus Butterbach-Bahl, Todd S. Rosenstock, Louis Verchot, Christopher Martius, Simone Rossi, Richard A. Houghton, Stephen Ogle, Benjamin Poulter, and Sytze de Bruin discussed the results and contributed to writing. Sytze de Bruin advised on statistical choices. 
Acknowledgements. This research was generously funded by the Standard Assessment of Mitigation Potential and Livelihoods in Smallholder Systems (SAMPLES) project as part of the CGIAR Research Program Climate Change, Agriculture, and Food Security (CCAFS). Funding also came from two European Union FP7 projects: GEOCarbon (283080) and Independent Monitoring of GHG Emissions-No. CLIMA.A.2/ETU/2014/0008. Partial funds came through CIFOR from the governments of Australia (Grant Agreement \#46167) and Norway (Grant Agreement \#QZA10/0468). In memory of Changsheng Li.

Edited by: A. Ito

Reviewed by: two anonymous referees

\section{References}

Abad-Viñas, R., Blujdea, V., Federici, S., Hiederer, R., Pilli, R., and Grassi, G.: Analysis and proposals for enhancing Monitoring, Reporting, and Verification of greenhouse gases from Land Use, Land Use Change and Forestry in the EU, Technical Report 071201/2011/211111/CLIMA.A2, Joint Research Centre, Ispra, Italy, available at: http://publications.jrc.ec.europa.eu/repository/ bitstream/JRC91414/lb-na-26813-en-n.pdf (last access: 18 October 2016), 2015.

Alencar, A., Nepstad, D., and Vera-Diaz, M. C.: Forest Understory Fire in the Brazilian Amazon in ENS and non-ENSO years: Area Burned and Committed Carbon Emissions, Earth Interact., 10, $1-17,2006$.

Anderson, K.: The inconvenient truth of carbon offsets, Nature News, 484, 7, doi:10.1038/484007a, 2012.

Anderson, K.: Duality in climate science, Nat. Geosci., 8, 898-900, 2015.

Asbjornsen, H., Gallardo-Hernández, C., Velázquez-Rosas, N., and García-Soriano, R.: Deep ground fires cause massive above- and below-ground biomass losses in tropical montane cloud forests in Oaxaca, Mexico, J. Trop. Ecol., 21, 427-434, 2005.

Baccini, A., Goetz, S. J., Walker, W. S., Laporte, N. T., Sun, M., Sulla-Menashe, D., Hackler, J., Beck, P. S. A., Dubayah, R., Friedl, M. A., Samanta, S., and Houghton, R. A.: Estimated carbon dioxide emissions from tropical deforestation improved by carbon-density maps, Nature Climate Change, 2, 182-185, 2012.

Balch, J., Brando, P., Nepstad, D. Coe, M., Silverio, D., Massad, T., Davidson, E., Lefebvre, P., Oliveira-Santos, C., Rocha, W., Cury, R., Parsons, A., and Carvalho, K.: The susceptibility of Southeastern Amazon Forests to Fire: Insights from a Large Scale Burn Experiment, BioScience, 65, 893-905, 2015.

Barlow, J. and Peres, C.: Fire-mediated dieback and compositional cascade in an Amazonian forest, Philos. T. R. Soc., 363, 17871794, 2008

Bradley, A. and Millington, C.: Spatial and temporal issues in determining biomass burning regimes in Bolivia and Peru, Int. J. Remote Sens., 27, 2221-2253, 2006.

Brando, P. M., Nepstad, D. C., Balch, J. K., Bolker, B., Christman, M. C., Coe, M., and Putz, F.: Fire-induced tree mortality in a neotropical forest: the roles of bark traits, tree size, wood density, and fire behaviour, Glob. Change Biol., 18, 630-641, 2012.

Brando, P. M., Balch, J. K., Nepstad, D. C., Morton, D., Putz, F., Coe, M., Silverio, D., Macedo, M., Davidson, E., Nobrega, C.,
Alencar, A., and Soares-Filho, B.: Abrupt increases in Amazonian tree mortality due to drought-fire interactions, P. Natl. Acad. Sci. USA, 11, 6347-6352, 2014.

Brienen, R., Phillips, O., Feldspausch, T., Gloor, E., Lloyd, J., Lopez-Gonzalez, G., Morteagudo-Mendoza, A., Malhi, Y., Lewis, S., Vasquez Martinez, R., Alexiades, M., Alvarez, E., Alvarez-Loayzada, P., and Zagt, R.: Long term decline of the Amazon carbon sink, Nature, 519, 344-361, 2015.

Canadell, J. and Schulze. D.: Global potential of biospheric carbon management for climate mitigation, Nat. Commun., 5, 52825293, 2014.

Ciais, P., Dolman, A. J., Bombelli, A., Duren, R., Peregon, A., Rayner, P. J., Miller, C., Gobron, N., Kinderman, G., Marland, G., Gruber, N., Chevallier, F., Andres, R. J., Balsamo, G., Bopp, L., Bréon, F.-M., Broquet, G., Dargaville, R., Battin, T. J., Borges, A., Bovensmann, H., Buchwitz, M., Butler, J., Canadell, J. G., Cook, R. B., DeFries, R., Engelen, R., Gurney, K. R., Heinze, C., Heimann, M., Held, A., Henry, M., Law, B., Luyssaert, S., Miller, J., Moriyama, T., Moulin, C., Myneni, R. B., Nussli, C., Obersteiner, M., Ojima, D., Pan, Y., Paris, J.-D., Piao, S. L., Poulter, B., Plummer, S., Quegan, S., Raymond, P., Reichstein, M., Rivier, L., Sabine, C., Schimel, D., Tarasova, O., Valentini, R., Wang, R., van der Werf, G., Wickland, D., Williams, M., and Zehner, C.: Current systematic carbon-cycle observations and the need for implementing a policy-relevant carbon observing system, Biogeosciences, 11, 3547-3602, doi:10.5194/bg-113547-2014, 2014.

Cochrane, M., Alencar, A., Schulze, M., Souza, C., Nepstad, D., Lefebvre, P., and Davidson, E.: Positive feedbacks in the fire dynamics of closed canopy tropical forests, Science, 284, 18321835, 1999.

Crowther, T., Thomas, S., Maynard, D., Baldrian, P., Covey, K., Frey, S., van Diepen, L., and Bradford, M.: Biotic interactions mediate soil microbial feedbacks to climate change, P. Natl. Acad. Sci. USA, 112, 7033-7038, 2015.

EDGAR: The Emissions Database for Global Atmospheric Research (2012) Part III: Greenhouse gas emissions, available at: http://edgar.jrc.ec.europa.eu/docs/IEA_PARTIII.pdf (last access: 18 October 2016), 2012.

Estrada, M., Lee, D., Murray, B., O'Sullivan, R., Penman, J., and Streck, C.: Land Use in a Future Climate Agreement, \# S-LMAQM-13-CA-1128 US Department of State, available at: http://merid.org/land-use-in-ADP/ (last access: 18 October 2016), 2014

FAO: The Agriculture sectors in the intended nationally determined contributions, Analysis, Environmental and natural resource management working paper 61, Rome, Italy, available at: http://www.fao.org/3/a-i5687e.pdf (last access: 18 October 2016), 2016

Federici, S., Tubiello, F., Salvatore, M., Jacobs, H., and Schmidhuber, J.: New estimates of $\mathrm{CO}_{2}$ forest emissions and removals: 1990-2015, Forest Ecol. Manag., 3, 89-98, 2015.

Federici, S., Grassi, G., Harris, N., Lee, D., Neeff, T., Penman, J., Sanz-Sanchez, M., and Wolosin M.: GHG fluxes from forests: an assessment of national reporting and independent science in the context of the Paris Agreement, Working Paper, UCLA, San Francisco, available at: http://www.climateandlandusealliance.org/wp-content/uploads/ 
2016/06/GHG_Fluxes_From_Forests_Working_Paper.pdf (last access: 18 October 2016), 2016.

Friedlingstein, P., Andrew, R., Rogelj, J., Peters G., Canadell J., Knutti, R., Luderer, G., Raupach, M., Schaeffer, M., van Vuuren, D., and Le Quéré, C.: Persistent growth of $\mathrm{CO}_{2}$ emissions and implications for reaching climate targets, Nat. Geosci., 7, 709715, 2014.

FRA: Forest Resources Assessments, http://www.fao.org/docrep/ 007/v5695e/V5695E00.htm (last access: 18 October 2016), 1990.

FRA: Forest Resources Assessment, http://www.fao.org/forestry/ fra/fra2005/en/ (last access: 18 October 2016), 2005.

FRA: Forest Resources Assessment, http://www.fao.org/forestry/ fra/fra2010/en/ (last access: 18 October 2016), 2010.

FRA: Forest Resources Assessment, http://www.fao.org/3/ a-i4793e.pdf (last access: 18 October 2016), 2015.

Frank, D., Reichstein, M., Bahn, M., Thonicke, K., Frank, D., Mahecha, M., Smith, P., van der Velde, M., Vicca, S., Babst, F., Beer, C., Buchmann N., Canadell, J., Ciais, P., Cramer, W., Ibrom, A., Miglietta, F., Poulter, B., Rammig, A., Seneviratne, S., Waltz, A., Wattenbach, M., Zavala, M., and Zscheischler, J.: Effects of climate extremes on the terrestrial carbon cycle: concepts, processes and potential future impacts, Glob. Change Biol., 21, 2861-2880, 2015.

Francey, R., Trudinger, C., Van der Schoot, M., Krummel, P., Steele, L., and Langenfelds, L.: Differences between trends in atmospheric $\mathrm{CO}_{2}$ and the reported trends in anthropogenic $\mathrm{CO}_{2}$ emissions, Tellus, 62B, 316-328, 2010.

Francey, R., Trudinger, C., Van der Schoot, M., Law, M., Krummel, P., Langenfelds, R., Steele, P., Allison, C., Stavert, A., Andres, R., and Rödenbeck, C.: Atmospheric verification of anthropogenic $\mathrm{CO}_{2}$ emission trends, Nature Climate Change, 3, 520525, 2013a.

Francey, R., Trudinger, C., Van der Schoot, M., Law, M., Krummel, P., Langenfelds, R., Steele, P., Allison, C., Stavert, A., Andres, R., and Rödenbeck, C.: Reply to Anthropogenic $\mathrm{CO}_{2}$ emissions, Nature Climate Change, 3, 603-604, 2013b.

Giglio, L., Randerson, J. T., van der Werf, G. R., Kasibhatla, P. S., Collatz, G. J., Morton, D. C., and DeFries, R. S.: Assessing variability and long-term trends in burned area by merging multiple satellite fire products, Biogeosciences, 7, 1171-1186, doi:10.5194/bg-7-1171-2010, 2010.

Grace, J., Mitchard, E., and Gloor, E.: Perturbations in the carbon budget of the tropics, Glob. Change Biol., 20, 3238-3255, 2014.

Grassi, G. and Dentener, F.: Quantifying the contribution of the Land Use Sector to the Paris Climate Agreement, The LULUCF sector within the Intended Nationally Determined Contributions, EUR 27561.JRC Science for Policy Report, Ispra, Italy, available at: http://publications.jrc.ec.europa.eu/ repository/bitstream/JRC98451/jrclulucf-indcreport.pdf (last access: 18 October 2016), 2015.

Grassi, G., Monni, S., Federici, S., Achard, F., and Mollicone, D.: Applying the conservativeness principle to REDD to deal with uncertainties of the estimates, Environ. Res. Lett., 3, 035005, doi:10.1088/1748-9326/3/3/035005, 2008.

Hansen, M., Stehman, S., and Potapov, P.: Quantification of global gross forest cover loss, P. Natl. Acad. Sci. USA, 107, 8650-8655, 2010.
Harris, N., Brown, S., Hagen, S., Saatchi, S., Petrova, S., Salas, W., Hansen, M., Potapov, P., and Lotsch, A.: Baseline Map of Carbon Emissions from Deforestation in Tropical Regions, Science, 336, 1576-1578, 2012.

Herrero, M., Havlik, P., Valin, H., Notenbaert, A., Rufino, M., Thornton, P., Blümmel, M., Weiss, F., Grace, D., and Obesteiner, M.: Biomass use, production, feed efficiencies, and greenhouse gas emissions from global livestock systems, P. Natl. Acad. Sci. USA, 110, 20888-20893, 2013.

Herold, M., Roman-Cuesta, RM., Heymell, V., Hirata, Y., Van Laake, P., Asner, G., Souza, C., Avitabile, V., and MacDicken, K.: A review of methods to measure and monitor historical carbon emissions from forest degradation. FAO, Unasylva, 238, 16-24, available at: http://www.fao.org/docrep/015/i2560e/ i2560e04.pdf (last access: 18 October 2016), $2011 \mathrm{a}$.

Herold, M., Roman-Cuesta, RM., Mollicone, D., Hirata, Y., Van Laake, P., Asner, G., Souza, C., Skutch, M., Avitabile, V., and MacDicken, K.: Options for monitoring and estimating hisoric carbon emissions from forest degradation in the context of REDD+, Carbon Balance and Management, 6, 13-20, $2011 \mathrm{~b}$.

Holmgren, P. Can we trust country-level data from global forest assessments?, available at: http://blog.cifor.org/34669/ can-we-trust-country-level-data-from-global-forest-assessments? fnl=en (last access: 18 October 2016), 2016.

Hooijer, A., Page, S., Canadell, J. G., Silvius, M., Kwadijk, J., Wösten, H., and Jauhiainen, J.: Current and future $\mathrm{CO}_{2}$ emissions from drained peatlands in Southeast Asia, Biogeosciences, 7, 1505-1514, doi:10.5194/bg-7-1505-2010, 2010.

Houghton, R. A.: The annual net flux of carbon to the atmosphere from changes in land use 1850-1990, Tellus B, 51, 298-313, 1999.

Houghton, R. A.: How well do we know the flux of $\mathrm{CO}_{2}$ from landuse change?, Tellus B, 62, 337-351, 2010.

Houghton, R. A.: Carbon emissions and the drivers of deforestation and forest degradation in the tropics, Current Opinion in Environmental Sustainability, 4, 597-603, 2012.

Houghton, R. A. and Hackler, J. L.: Carbon Flux to the Atmosphere from Land-Use Changes: 1850 to 1990, ORNL/CDIAC131, NDP-050/R1, Carbon Dioxide Information Analysis Center, US Department of Energy, Oak Ridge National Laboratory, Oak Ridge, Tennessee, USA, 2001.

Houghton, R. A., House, J. I., Pongratz, J., van der Werf, G. R., DeFries, R. S., Hansen, M. C., Le Quéré, C., and Ramankutty, N.: Carbon emissions from land use and land-cover change, Biogeosciences, 9, 5125-5142, doi:10.5194/bg-9-5125-2012, 2012.

IPCC: Intergovernmental Panel on Climate Change: Good Practice Guidance for Land Use, Land Use and Forestry, IPCC National Greenhouse Gas Inventory Programme, edited by: Penman, J., Gytarsky, M., Hiraishi, T., Krug, T., Kruger, D., Ppatti, R., Buendia, L., Miwa, K., Ngara, T., Tanabe, K., and Wagner, F., IGES, Kanagawa, Japan, http://www.ipcc-nggip.iges.or.jp/ public/gpglulucf/gpglulucf_files/GPG_LULUCF_FULL.pdf (last access: 18 October 2016), 2003.

IPCC: Intergovernmental Panel on Climate Change: AFOLU Guidelines for National Greenhouse gas Inventories, Vol. 4: Agriculture, Forestry and Other Land Use, Eggleston, S., Buendia, L., Miwa, K., Ngara, T., and Tanabe, K., IGES, Kanagawa, Japan, http://www.ipcc-nggip.iges.or.jp/public/2006gl/vol4.htm (last access: 18 October 2016), 2006. 
IPCC: Intergovernmental Panel on Climate Change.: Summary for Policymakers, in: Climate Change 2014: Mitigation of Climate Change.Contribution of Working Group III to the Fifth Assessment Report of the Intergovernmental Panel on Climate Change, edited by: Edenhofer, O., Pichs-Madruga, R., Sokona, Y. E., Farahani, E., Kadner, S., Seyboth, K., Adler, A., Baum, I., Brunner, S., Eickemeier, P., Kriemann, B., Savolainen, J., Schlomer, S., von Stechow, C., Zwickel, T., and Minx, J. C., Cambridge University Press, Cambridge, United Kingdom and New York, NY, USA, 2014.

Laurance, W. and Williamson, G.: Positive feedbacks among forest fragmentation, drought and climate change in the Amazon, Conserv. Biol., 15, 1529-1535, 2001.

Le Quéré, C., Peters, G. P., Andres, R. J., Andrew, R. M., Boden, T. A., Ciais, P., Friedlingstein, P., Houghton, R. A., Marland, G., Moriarty, R., Sitch, S., Tans, P., Arneth, A., Arvanitis, A., Bakker, D. C. E., Bopp, L., Canadell, J. G., Chini, L. P., Doney, S. C., Harper, A., Harris, I., House, J. I., Jain, A. K., Jones, S. D., Kato, E., Keeling, R. F., Klein Goldewijk, K., Körtzinger, A., Koven, C., Lefèvre, N., Maignan, F., Omar, A., Ono, T., Park, G.-H., Pfeil, B., Poulter, B., Raupach, M. R., Regnier, P., Rödenbeck, C., Saito, S., Schwinger, J., Segschneider, J., Stocker, B. D., Takahashi, T., Tilbrook, B., van Heuven, S., Viovy, N., Wanninkhof, R., Wiltshire, A., and Zaehle, S.: Global carbon budget 2013, Earth Syst. Sci. Data, 6, 235-263, doi:10.5194/essd-6-2352014, 2014.

Li, C., Salas, W., DeAngelo, B., and Rose, S.: DNDC9.5 in EPA (2013) Global Mitigation of non- $\mathrm{CO}_{2}$ Greenhouse Gases: 2010-2030, EPA Technical Report-430-R-13-011, US, Country data available at: https://www.epa.gov/ghgemissions/ global-greenhouse-gas-emissions-data (last access: 18 October 2016), 2013.

Montzka, S. A., Dlugokencky, E. J., and Butler, J. H.: Non- $\mathrm{CO}_{2}$ greenhouse gases and climate change, Nature, 476, 43-51, 2011.

Morton, D. C., Le Page, Y., DeFries, R., Collatz, G. J., and Hurtt, G. C.: Understory fire frequency and the fate of burned forests in southern Amazonia, Philos. T. R. Soc. B, 368, 20120163, doi:10.1098/rstb.2012.0163, 2013.

Negron-Juarez, RI., Chambers, J., Guimaraes, G., Zeng, H., Raupp, C., Marra, D., Ribeiro, G., Saatchi, S., Nelson, B., and Higuchi, N.: Widespread Amazon forest tree mortality from a single cross-basin squall line event, Gephys. Res. Lett., 37, L16701, doi:10.1029/2010GL043733, 2010.

Numata, I., Cochrane, M., Roberts, D., Soares, J., Souza, C., and Sales, M.: Biomass collapse and carbon emissions from forest fragmentation in the Brazilian Amazon, J. Geophys. Res., 115, G03027, doi:10.1029/2009JG001198, 2010.

Ogle, S.: in EPA (2013) Global Mitigation of non- $\mathrm{CO}_{2}$ Greenhouse Gases: 2010-2030, EPA Technical Report-430-R-13-011, (data available upon request), Country data available at: https://www. epa.gov/ghgemissions/global-greenhouse-gas-emissions-data, 2013.

Oliveras, I., Malhi, Y., Salinas, N., Huaman, V., Urquiaga-Flores, E., Kala-Mamani, J., Quintano-Loaiza, J. A., Cuba-Torres, I., Lizarraga-Morales, N., and Roman-Cuesta, R. M.: Changes in forest structure and composition after fire in tropical montane cloud forests near the Andean treeline, Plant Ecol. Divers., 7, 329-340, 2013.
Oliveras, I. Anderson, D., and Malhi, Y.: Application of remote sensing to understanding fire regimes and biomass burning emissions of the tropical Andes, Global Biogeochem. Cy., 28, 480 496, 2014.

Pelletier, J., Busch, J., and Potvin, C.: Addressing uncertainty upstream or downstream of accounting for emissions reductions from deforestation and forest degradation, Climatic Change, 130, 635-648, 2015.

Peters, G. P., Davis, S. J., and Andrew, R.: A synthesis of carbon in international trade, Biogeosciences, 9, 3247-3276, doi:10.5194/bg-9-3247-2012, 2012.

Phillips, O., Aragao, L., Lewis, S., Fisher, J., Lloyd, J., LópezGonzález, G., Malhi, Y., Monteagudo, A., Peacock, J., Quesada, C., van der Heijden, G., Almeida, S., Amaral, L., Arroyo, L., Aymard, G., Baker, T., Bánki, O., Blanc, L., Bonal, D., Brando, P., Chave, J., Cristina, A., Oliveira, A., Dávila Cardozo, N., Czimczik, C., Feldspausch, T., Freitas, M. A., Gloor, E., Higuchi, N., Jiménez, E., Lloyd, G., Neil, D., Nepstad, D., Patino, S., Penuela, MC., Prieto, A., Ramírez, F., Schwarz, M., Silva, J., Silveira, M., Thomas, A., ter Steege, H., Stropp, J., Vásquez, R., Zelazowski, P., Alvarez Dávila, E., Andelman, S., Andrade, A., Chao, K. J.,Erwin, T., Di Fiore, A., Honorio, E., Keeling, H., Kileen, T., Laurance, W., Pena Cruz, A., Pitman, N., Núnez-Vargas, P., Ramírez-Angulo, H., Rudas, A., Salamao, R., Silva, N., Terborfgh, J., and Torres-Lezama, A.: Drought Sensitivity of the Amazon Rainforest, Science, 323, 1344-1347, 2009.

Phillips, O., van der Heijden, G., Lewis, S., López-Gonzákez, G., Aragao, L., Malhi, Y., Monteagudo, A., Almeida, S., Alvarez Dávila, E., Amaral, I., Andelman, S., Andrade, A., Arroyo, L., Aymard, G., Baker, T., Blanc, L., Bonal, D., Alves de Oliveira, A. C., Chao, K. J., Dávila Cardozo, N., da Costa, L., Feldpausch, T., Fisher, J., Fyllas, N., Freitas, M. A., Galbraith, D., Gloor, E., Higuchi, N., Honorio, E., Jiménez, E., Keeling, H., Kileen, T., Lovett, J., Meir, P., Mendoza, C., Morel, A., Nunez Vargas, P., Patino, S., Peh, K., Peza Cruz, A., Prieto, A., Quesada, C., Ramírez, F., Ramírez, H., Sonké, B., Sota Thomas, A., Stropp, J., Taplin, J., Vasquez, R., and Vilanova, E.: Drought-mortality relationships for tropical forests, New Phitol., 187, 631-646, 2010.

Poorter, L., Bongers, F., Aide, M., Almeyda Zambrano, A., Balvanera, P., Becknell, J., Boukili, V., Brancalion, P., Broadbent, E., Cahzdon, R., Craven, D., Almeida-Cortez, J., Cabral, G., de Jong, B., Denslow, J., Dent, D., DeWalt, S., Dupuy, J., Durán, S., Espírito-Santo, M., Fandino, M., César, R., Hall, J., Hernández-Stefanoni, J. L., Jakovac, C., Junqueira, A., Kennard, D., Letcher, S., Licona, JC., Lohbeck, M., Marín-Spiotta, E., Martínez-Ramos, M., Massoca, P., Meave, J., Mesquita, R., Mora, F., Munoz, R., Muscarella, R., Nunes, Y., Ochoa-Gaona, S., de Oliveira, A., Orihuela-Belmonte, E., Pena-Claros, M., Pérez-García, E., Piotto, D., Powers, J., Rodríguez-Velazquez, J., Romero-Perez, E., Ruiz, J., Saldarriaga, J., Sanchez-Azofeifa, A., Schwartz, N., Steininger, M., Swenson, N., Toledo, M., Uriarte, M., Vizcarra Bentos, T., Williamson, B., and Rozendaal, D.: Biomass resilience of Neotropical secondary forests, Nature, 530, 211-214, 2016.

Pütz, S., Groeneveld, J., Henle, K., Knogge, C., Martensen, A., and Metz, M.: Long-term carbon loss in fragmented Neotropical forests, Nat. Commun., 5, 5037-5045, 2014. 
Read, L. and Lawrence, D.: Recovery of biomass following shifting cultivation in dry tropical forests of the Yucatan, Ecol. Appl., 13, 85-97, 2003.

Richards, M., Bruun, T., Campbell, B. M., Gregersen, L., Huyer, S., Kuntze, V., Madsen, T., Oldvig, M., and Vasileiou, I.: How countries plan to address agricultural adaptation and mitigation: An analysis of Intended Nationally Determined Contributions, CGIAR Research Program on Climate Change, Agriculture and Food Security (CCAFS), Copenhagen, 2015.

Roman-Cuesta, R. M., Gracia, M., and Retana, J.: Environmental and human factors influencing fire trends in Enso and non-Enso years in tropical Mexico, Ecol. Appl., 13, 1177-1192, 2003.

Román-Cuesta, R. M., Salinas, N., Asbjornsen, H., Oliveras, I., Huaman, V., Gutiérrez, Y., Puelles, L., Kala, J., Rojas, M., Astete, R., Jordán, D., Silman, M., Mosandl, R., Weber, M., Stimm, B., Gunter, S., Knoke, T., and Malhi, Y.: Implications of fires on carbon budgets in Andean cloud montane forest: The importance of peat soils and tree resprouting, Forest Ecol. Manage., 261, 19871997, 2011

Roman-Cuesta, R. M., Rufino, M. C., Herold, M., Butterbach-Bahl, K., Rosenstock, T. S., Herrero, M., Ogle, S., Li, C., Poulter, B., Verchot, L., Martius, C., Stuiver, J., and de Bruin, S.: Hotspots of gross emissions from the land use sector: patterns, uncertainties, and leading emission sources for the period 2000-2005 in the tropics, Biogeosciences, 13, 4253-4269, doi:10.5194/bg-134253-2016, 2016.

Romijn, E., Herold, M., Koistra, L., Murdiyarso, D., and Verchot, L.: Assessing capacities of non-Annex I countries for national forest monitoring in the context of REDD+, Environ. Sci. Pol., 19-20, 33-48, 2012.

Romijn, E., Lantican, C., Herold, M., Lindquist, E., Ochieng, R., Wijaya, A., Murdiyarso, D., and Verchot, L.: Assessing change in national forest monitoring capacities of 99 tropical countries, Forest Ecol. Manage., 352, 109-123, 2015.

Saatchi, S., Harris, N., Brown, S., Lefsky, M., Mitchard, E., Salas, W., Zutta, B., Buermann, W., Lewis, S., Hagen, S., Petrova, S., White, L., Silman, M., and Morel, A.: Benchmark map of forest carbon stocks in tropical regions across three continents, P. Natl. Acad. Sci. USA, 108, 9899-9904, 2011.

Simula, M.: Towards defining forest degradation: comparative analysis of existing definitions, Forest Resources Assessment, Working Paper 154, FAO, Rome, Italy, 2009, available at: ftp://ftp.fao. org/docrep/fao/012/k6217e/k6217e00.pdf (last access: 18 October 2016), 2009.

Sist, P., Rutishauser, E., Peña-Claros, M., Shenkin, A., Herault, B., Blanc, L., Baraloto, C., Baya, F., Benedet, F., Da Silva, K. E., Descroix, L., Ferreira, J., Gourlet-Fleury, S., Guedes,M.C., Bin Harun, I., Jalonen, R., Kanashiro, M., Krisnawati, H., Kshatriya, M., Lincoln, P., Mazzei, L., Medjibe, V. P., Nasi, R., D’oliveira, M. V. N., de Oliveira, L. C., Picard, N., Pietsch, S., Pinard, M., Priyadi, H., Putz, F. E., Rodney, K., Rossi, V., Roopsind, A., Ruschel, A., Shari, N. H. Z., Rodrigues de Souza, C., Susanty, F. H., Sotta, E. D., Toledo, M., Vidal, E., West, T. A. P., Wortel, V., and Yamada, M.: The Tropical Managed Forests Observatory: a research network addressing the future of logged forests, Appl. Veg. Sci., 18, 171-174, 2015

Sitch, S., Friedlingstein, P., Gruber, N., Jones, S. D., MurrayTortarolo, G., Ahlström, A., Doney, S. C., Graven, H., Heinze, C., Huntingford, C., Levis, S., Levy, P. E., Lomas, M., Poul- ter, B., Viovy, N., Zaehle, S., Zeng, N., Arneth, A., Bonan, G., Bopp, L., Canadell, J. G., Chevallier, F., Ciais, P., Ellis, R., Gloor, M., Peylin, P., Piao, S. L., Le Quéré, C., Smith, B., Zhu, Z., and Myneni, R.: Recent trends and drivers of regional sources and sinks of carbon dioxide, Biogeosciences, 12, 653679, doi:10.5194/bg-12-653-2015, 2015.

Smith, P., Martino, D., Cai, Z., Gwary, D., Janzen, H.,Kumar, P., McCarl, B., Ogle, S., O’Mara, F., Rice, C., Scholes, B., Sirotenko, O., Howden, M., McAllister, T., Pan, G., Romanenkov, V., Schneider, U., Towprayoon, S., Wattenbach, M., and Smith, J.: Greenhouse gas mitigation in agriculture, Philos. T. R Soc. B, 363, 789-813, 2008.

Smith, P., Bustamante, M., Ahammad, H., Clark, H., Dong, H., Elsiddig, E., Harberl, H., Harper, R., House, J., Jafari, M., Masera, O., Mbow, C., Ravindranath, N., Rice, C., Robledo Abad, C., Romanisvskaya, A., Sperling, F., Tubiello, F., Berndes, G., Bolwig, S., Bottcher, H., Bright, R., Cherubini, F., Chum, H., Corbera, E., Creutzig, F., Delucchi, M., Faaij, A., Fargione, J., Hansel, G., Heath, G., Herrero, M., Houghton, R., Jacobs, H., Jain, A., Kato, E., Lucon, O., Pauly, D., Popp, A.,Porer, P., Sohi, S., Stocker, B., Stromman, A., Suh, S., and van Minnen, J.: Agriculture, Forestry and Other Land Use (AFOLU), in: Climate Change 2014: Mitigation of Climate Change, Contribution of Working Group III to the Fifth Assessment Report of the Intergovernmental Panel on Climate Change, edited by: Edenhofer, O., Pichs-Madruga, R., Sokona, Y. E., Farahani, E., Kadner, S., Seyboth, K., Adler, A., Baum, I., Brunner, S., Eickemeier, P., Kriemann, B., Savolainen, J., Schlomer, S., von Stechow, C., Zwickel, T., and Minx J. C., Cambridge University Press, Cambridge, United Kingdom and New York, NY, USA, 2014.

Streck, C.: Forests and Land Use in the Paris Agreement, Climate Focus, 2015, available at: http://www.climatefocus.com/sites/ default/files/20151223LandUseandtheParisAgreementFIN.pdf, (last access: 18 October 2016), 2015.

Tian, H., Lu, C., Ciais, P., Michalak, A., Canadell, J., Saikawa, E., Huntzinger, D., Gurney, K., Sitch, S., Zhang, B., Yang, J., Bousquet, P., Bruhwiler, L., Chen, G., Dlugokencky, E., and Wofsy, S.: The terrestrial biosphere as a net source of greenhouse gases to the atmosphere, Nature, 531, 225-228, 2016.

Tubiello, F., Salvatore, M., Rossi, S., Ferrara, A., Fitton, N., and Smith, P.: The FAOSTAT database of greenhouse gas emissions from agriculture, Environ. Res. Lett., 8, 015009-19, doi:10.1088/1748-9326/8/1/015009, 2013.

Tubiello, F., Salvatore, M., Cóndor Golec, R., Ferrara, A., Rossi, S., Biancalani, R., Federici, S., Jacobs, H., and Flammini, A.: Agriculture, Forestry and Other Land Use Emissions by Sources and Removals by Sinks 1990-2011 Analysis, Working Paper Series ESS/14-02.FAO Statistical Division, Rome, Italy, available at: http://www.fao.org/docrep/019/i3671e/i3671e.pdf (last access: 18 October 2016), 2014.

Tubiello, F., Salvatore, M., Ferrara, A., House, J., Federici, S., Rossi, S., Biancalani, R., Condor Golec, R., Jacobs, H., Flammini, A., Prosperi, P., Cardenas-Galindo, P., Schmidhuber, J., Sanz Sanchez, M. J., Srivastava, N., and Smith, P.: The contribution of Agriculture, Forestry and other Land Use Activities to Global Warming, 1990-2012, Glob. Change Biol., 21, 26552660, 2015. 
Turetsky, M., Benscoter, B., Page, S., Rein, G., Van der Werf, G., and Watts, A.: Global vulnerability of peatlands to fire and carbon loss, Nat. Geosci., 8, 11-14, 2015.

Uhl, C. and Kauffman, J.: Deforestation effects on fire susceptibility and the potential response of the tree species to fire in the rainforest of the eastern Amazon, Ecology, 71, 437-449, 1990.

USEPA: United States Environmental Protection Agency, Global Anthropogenic Non- $\mathrm{CO}_{2}$ Greenhouse Gas Emissions: 1990-2030, EPA 430-R-12-006, Washington, DC, available at: https://www.epa.gov/ghgemissions/ global-greenhouse-gas-emissions-data (last access: 18 October 2016), 2012.

USEPA: United States Environmental Protection Agency, Global Mitigation of non- $\mathrm{CO}_{2}$ Greenhouse Gases: 2010 2030, Technical Report-430-R-13-011, available at: https://www3.epa.gov/climatechange/Downloads/EPAactivities/ MAC_Report_2013.pdf (last access: last access: 18 October 2016), 2013.

Valentini, R., Arneth, A., Bombelli, A., Castaldi, S., Cazzolla Gatti, R., Chevallier, F., Ciais, P., Grieco, E., Hartmann, J., Henry, M., Houghton, R. A., Jung, M., Kutsch, W. L., Malhi, Y., Mayorga, E., Merbold, L., Murray-Tortarolo, G., Papale, D., Peylin, P., Poulter, B., Raymond, P. A., Santini, M., Sitch, S., Vaglio Laurin, G., van der Werf, G. R., Williams, C. A., and Scholes, R. J.: A full greenhouse gases budget of Africa: synthesis, uncertainties, and vulnerabilities, Biogeosciences, 11, 381-407, doi:10.5194/bg11-381-2014, 2014. van der Werf, G. R., Randerson, J. T., Giglio, L., Collatz, G. J., Mu, M., Kasibhatla, P. S., Morton, D. C., DeFries, R. S., Jin, Y., and van Leeuwen, T. T.: Global fire emissions and the contribution of deforestation, savanna, forest, agricultural, and peat fires (19972009), Atmos. Chem. Phys., 10, 11707-11735, doi:10.5194/acp10-11707-2010, 2010.

Werner, C., Butterbach-Bahl, K., Haas, E., Hickler, T., and Kiese, R.: A global inventory of $\mathrm{N}_{2} \mathrm{O}$ emissions from tropical rainforest soils using a detailed biogeochemical model, Global Biogeochem. Cy., 21, GB3010, doi:10.1029/2006GB002909, 2007. 